\title{
A Review of Metallic Bipolar Plates for Proton Exchange Membrane Fuel Cells: Materials and Fabrication Methods
}

\author{
Shahram Karimi, ${ }^{1,2}$ Norman Fraser, ${ }^{1}$ Bronwyn Roberts, ${ }^{1}$ and Frank R. Foulkes ${ }^{2}$ \\ ${ }^{1}$ Alternative Energy Engineering Technology Program, Lambton College, 1457 London Road, Sarnia, ON, Canada N7S 6K4 \\ ${ }^{2}$ Department of Chemical Engineering and Applied Chemistry, University of Toronto, 200 College Street, Toronto, \\ ON, Canada M5S 3E5
}

Correspondence should be addressed to Shahram Karimi, shahram.karimi@lambtoncollege.ca

Received 20 March 2012; Accepted 13 June 2012

Academic Editor: Meilin Liu

Copyright () 2012 Shahram Karimi et al. This is an open access article distributed under the Creative Commons Attribution License, which permits unrestricted use, distribution, and reproduction in any medium, provided the original work is properly cited.

\begin{abstract}
The proton exchange membrane fuel cell offers an exceptional potential for a clean, efficient, and reliable power source. The bipolar plate is a key component in this device, as it connects each cell electrically, supplies reactant gases to both anode and cathode, and removes reaction products from the cell. Bipolar plates have been fabricated primarily from high-density graphite, but in recent years, much attention has been paid to developing cost-effective and feasible alternative materials. Two different classes of materials have attracted attention: metals and composites. This paper offers a comprehensive review of the current research being carried out on metallic bipolar plates, covering materials and fabrication methods.
\end{abstract}

\section{Introduction}

Proton exchange membrane fuel cells (PEMFCs) are electrochemical devices that convert the chemical energy of reactants (a fuel and an oxidant) directly to electrical energy in the form of low voltage direct current (DC) electricity and heat. They have been receiving significant attention due to their high power density, energy efficiency, and environmentally friendly characteristics [1-4]. However, one of the major impediments to making them a viable power source is the high manufacturing cost of a number of key components, including catalyst layers [5-12], solid polymer electrolyte (SPE) membrane [13-16], and bipolar plates [1722].

The practical operating voltage from a single cell-also known as a membrane-electrode assembly (MEA) - is about $0.7 \mathrm{~V}$. Desired voltages are obtained by connecting cells in series; this is accomplished by inserting a highly conductive material (e.g., a bipolar plate) between two parallel MEAs. Such plates are by volume, weight, and cost the most critical component of a fuel cell stack $[23,24]$, and account for more than $40 \%$ of the total stack cost and about $80 \%$ of the total weight [25-31]. As a result, there have been significant R\&D activities in the past few years to lower their cost, reduce their size, and improve their performance and lifetime. Bipolar plates perform a number of critical functions simultaneously in a fuel cell stack to ensure acceptable levels of power output and a long stack lifetime. They act as a current conductor between adjacent MEAs, provide pathways for reactant gases (hydrogen and oxygen or air), facilitate water and heat management throughout the stack, and provide structural support for the whole stack. Accordingly, they must exhibit excellent electrical and thermal conductivity, corrosion resistance, mechanical and chemical stability, and very low gas permeability. Furthermore, raw materials must be widely available at reasonable cost and be amenable to rapid and cost-effective fabrication methods and processes [23]. An exploded view of a PEM fuel cell stack is shown in Figure 1.

Due to the multifaceted characteristics of bipolar plates and a wide combination of physical and chemical properties that are often contradictory, a large number of candidates has been proposed and investigated over the years. As a result, a set of targets and requirements has been established to 


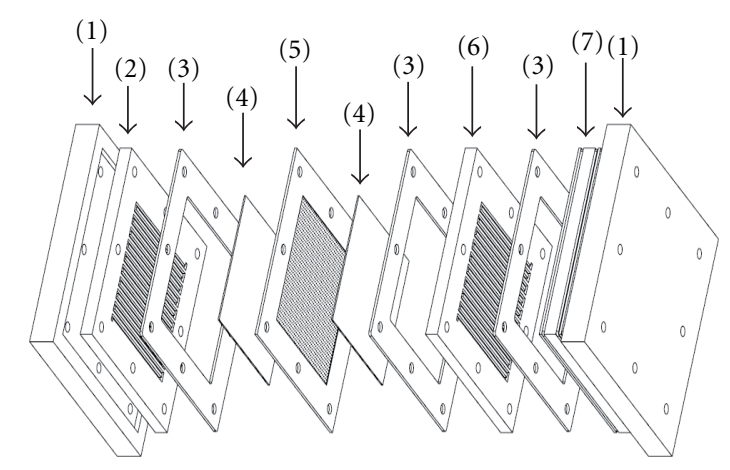

FIGURe 1: An exploded view of a PEM fuel cell stack. (1) clamping plate; (2) End plate; (3) gasket; (4) gas diffusion layer; (5) SPE/catalyst layer; (6) bipolar plate; (7) additional stacked cells.

develop suitable material for the fabrication of bipolar plates. A summary of such requirements and targets is presented below $[23,24]$.

(i) Bulk electrical conductivity (in-plane): $>100 \mathrm{~S} \mathrm{~cm}^{-1}$.

(ii) Hydrogen permeability: $<2 \times 10^{-6} \mathrm{~cm}^{3} \mathrm{~cm}^{-2} \mathrm{~s}^{-1}$.

(iii) Corrosion rate: $<16 \times 10^{-6} \mathrm{~A} \mathrm{~cm}^{-2}$.

(iv) Interfacial contact resistance: $<20 \mathrm{~m} \Omega \mathrm{cm}^{2}$ at $150 \mathrm{~N}$ $\mathrm{cm}^{-2}$.

(v) Tensile strength: $>41 \mathrm{MPa}$.

(vi) Flexural strength: $>59 \mathrm{MPa}$.

(vii) Thermal conductivity: $>10 \mathrm{~W} \mathrm{~m}^{-1} \mathrm{~K}^{-1}$.

(viii) Thermal stability: up to $120^{\circ} \mathrm{C}$.

(ix) Chemical and electrochemical stability in acidic environments.

(x) Low thermal expansion.

(xi) Acceptable hydrophobicity (or hydrophilicity).

The requirements for specific bipolar plates are ultimately dictated by the type of application and operating conditions under which the fuel cell stack is utilized. Thus, the bipolar plate requirements for mobile and transportation applications are considerably different from those for stationary applications. In the former case, the plates must be lightweight, thin, and be able to withstand harsh and changing environments, where operating temperature, humidity, and loads continuously change to meet demands. In the latter case, size and volume of the bipolar plates, and ultimately the fuel stack, are not critical; however, durability is crucial. As with many other systems, for terrestrial applications, economics play a vital role.

\section{Materials}

Bipolar plate materials are broadly divided into metallicand carbon-based. Initially, carbon-based bipolar plates, particularly high-density graphite, dominated the R\&D activities and other applications [32]. This stemmed from the excellent chemical and electrical properties of graphite in the harsh operating PEMFC environment. However, its use was mainly limited to stationary and laboratory settings, where lightweight and low volume plates were not critical. Additionally, the high cost of machining gas channels and the material's inherent brittleness retarded its use in terrestrial applications, including the mobile and transportation fields, where cost-effective mass production processes are highly desired and often mandatory [17-20, 32]. As a result, metallic bipolar plates have recently attracted the attention of the scientific community. Although, at first, metals (excluding noble metals) may seem to exhibit most of the desired characteristics, including high thermal and electrical conductivity, low gas permeability, ease of manufacturing and relatively low cost, they have a number of disadvantages such as chemical instability in the corrosive environments of PEMFCs, leading to corrosion and formation of a thin oxide layer on their surface. The former can poison the solid polymer electrolyte as well as the catalyst layer by releasing corrosion byproducts $\left(\mathrm{Fe}^{3+}, \mathrm{Cr}^{3+}, \mathrm{Ni}^{2+}\right.$, etc. $)$, while the latter can significantly increase the interfacial contact resistance (ICR) between metallic plates and gas diffusion layers, resulting in inferior fuel cell performance. A number of processes have been proposed to improve the corrosion resistance and interfacial contact resistance of metallic bipolar plates; these include the application of a thin, conductive protective layer on the surface of the metallic plates as well as other surface modification techniques. In addition to a large number of publications on different types of bipolar plates, several review papers have been published on the material type, and manufacturing processes. Early works include those by Hermann et al. [30], Borup and Vanderborgh [33], Mehta and Cooper [34], Cooper [35], Yuan et al. [36], and Brett and Brandon [37], while more recent reviews include those by Tawfik et al. [38], Li et al. [39], Wang and Turner [40], and Hamilton and Pollet [41]. Despite the large number of studies conducted by various groups and evidenced by the significant number of publications over the last two decades, no single material has been identified to satisfy all the requirements listed above $[40,41]$.

2.1. Graphite Bipolar Plates. Carbon is found in many compounds and is the building block of many materials. It is found free in nature in three allotropic forms: graphite, 
amorphous carbon, and diamond. Another type of carbon, known as buckminster fullerene, has been recently added to the list. While diamond is one of the hardest substances known, graphite is soft and slippery. It is a crystalline form of carbon, in which each carbon atom is covalently bonded to three adjacent carbon atoms in the same plane to form six-member structures that, in turn, connect to create flat planes or sheets. The bond angle is $120^{\circ}$ and each carbon atom uses only three of its four unpaired electrons to form strong covalent bonds with three other carbon atoms in the same plane. This arrangement creates a "free" network of electrons, where each carbon atom contributes one free (i.e., unpaired) electron to the network. One of the consequences of such an arrangement is the ability of graphite to conduct electrical current along the planes of carbon atoms, which is a highly desirable property in the manufacture of bipolar plates. However, the bond between layers is through weak van der Waals forces with larger distances, which is about $2 \%$ of the bond energy within the planes $(620-720 \mathrm{~kJ} / \mathrm{gram}$ atom versus $5.0-17.0 \mathrm{~kJ} / \mathrm{gram}$ atom) [32]. Consequently, graphite exhibits weak flexural strength and is more prone to fracture during fabrication than other bipolar plate materials $[38,42$, 43].

Nevertheless, early fuel cell research focused on graphite-natural and synthetic — as a leading material for bipolar plate construction on account of its corrosion resistance, lack of poisoning agents, and low surface contact resistance or interfacial contact resistance. However, as stated previously, graphite is brittle, permeable to gases, and exhibits poor mechanical properties. Furthermore, it is not suitable for mass production, since the fabrication of channels in the plate surfaces requires machining, a time-consuming and costly process [24, 31, 32, 38, 42]. Additionally, after processing such as resin impregnation is often required to ensure the impermeability of graphite plates to reactant gases. Finally, the molecular structure, porosity and flexural strength of graphite have prevented a much-needed reduction in the thickness of such bipolar plates, limiting them to about $4-6 \mathrm{~mm}$ in thickness $[44,45]$. This has resulted in fuel cell stacks with low power density, which is not acceptable for transportation and mobile applications. However, graphite is still considered the standard material against which most of today's bipolar plate materials are measured. The limitations as well as the advantages of graphite have led fuel cell researchers to investigate alternate materials that meet the strict requirements of high-performance, cost-effective, and durable hydrogen fuel cells.

\subsection{Metallic Bipolar Plates}

2.2.1. Introduction. In recent years, metallic bipolar plates have been attracting the attention of the research community because of their desirable characteristics, such as high electrical conductivity, formability and manufacturability, gas impermeability, and superior mechanical properties [46, 47]. Metal plates offer higher strength, toughness and shock resistance than graphite plates, and their unique mechanical properties allow for fabrication of thinner plates. Although metals offer many advantages, they are, however, more susceptible to corrosion, which can adversely affect their performance and durability $[43,46]$. It is important to note that corrosion can take place both at the anode and the cathode of an operating PEMFC. At the anode, the protective metal oxide layer can be reduced as a result of the presence of a reducing environment, leading to unwanted hydride formation and dissolution of the metal in water. This problem is amplified by the addition of water vapour to the incoming fuel stream. This can potentially increase the risk of polymer electrolyte membrane contamination and can adversely impact the activity of the catalyst layer. At the cathode, the existing oxidizing environment can substantially increase the corrosion rate of metallic bipolar plates, leading to performance losses and even premature failure of the whole stack.

Surface modification techniques have been proposed and corrosion-resistant coatings have been developed to minimize these effects $[40,41]$. Metals also are much denser than graphite or composites, hence a substantial reduction in their thickness is necessary [43]. Stainless steel, aluminum alloys, titanium alloys, nickel alloys, copper alloys, and metal-based composites have been used to fabricate plates. Research has mainly been focused on iron-based alloys, such as stainless steels, because of their low cost; however, more recently, considerable efforts have been expended to use noble metals, aluminum, and titanium as the material of choice for fabricating bipolar plates.

2.2.2. Types of Metals. Metals, such as titanium and stainless steels, exhibit excellent mechanical properties and have very low gas permeation rates. They are also suitable for mass production with low scrap rates and are stable in a PEM fuel cell environment where low $\mathrm{pH}$ values are common. The good corrosion characteristics of stainless steels and titanium are attributed to the passivation of such metals in the presence of oxygen, where a protective oxide metal film is formed on their surface. Such an advantage comes at the expense of metal conductivity, which is hindered by the presence of such insulating protective layers [48]. In order to make these metallic plates conductive, it becomes necessary to remove such oxide films or reduce their thickness to an acceptable level and apply a conductive and corrosionresistant film to retard the further formation of oxide films and decrease their interfacial contact resistance.

Stainless steels, by far, have been the focus of ongoing recent research. The primary selection criterion for stainless steel (SS) bipolar plates is the $\mathrm{Cr}, \mathrm{N}$, and Mo content, in accordance with the pitting resistance equivalent $[49,50]$. Stainless steels come in different compositions and, accordingly, behave differently in various environments. Stainless steel bipolar plates with different compositions have been used extensively by different workers [51-55]. In an early work, Davies et al. [53] conducted a series of experiments on three types of stainless steel bipolar plates, namely, 310L, 316L, and 904L. They reported that 904L performed the best while 316L exhibited the worst 
performance in an environment similar to that of a PEM fuel cell. In another published paper, the same authors [54] utilized Auger Electron Spectroscopy (AES) to determine the thickness of the passive film on the surface of various stainless steel bipolar plates. It was reported that the thickness of the passive layer decreases with the alloying element content, and often varies between 3 to $5 \mathrm{~nm}$.

316 stainless steel has been receiving increasing attention as a replacement for nonporous graphite in bipolar plates. Wang and Northwood [25] investigated the influence of oxygen- and hydrogen-containing environments on the corrosion behavior of such bipolar plates. Intergranular and pitting corrosion in both the oxygen- and hydrogencontaining environments were reported with a greater corrosion resistance shown by $316 \mathrm{~L}$ SS bipolar plates in simulated cathodes. This has been attributed to the cathodic protection ability of the oxygen-containing environments. In addition, metal ion concentrations of about 25 and $42 \mathrm{ppm}$ at the anode and cathode, respectively, after $5000 \mathrm{~h}$ of operation are reported utilizing potentiostatic tests (using ICP-OES).

It was concluded that 316L SS bipolar plates must be coated, since such levels of ion concentrations can adversely affect the membrane. The above finding was confirmed by $\mathrm{Ma}$ et al. [56], who studied the corrosion behavior of $316 \mathrm{~L}$ SS bipolar plates and concluded that such plates must be coated since they can corrode in both anode and cathode environments. It is thus common practice to coat $316 \mathrm{~L}$ and 316 stainless steels bipolar plates for use in PEM fuel cells [57-60].

Other types of stainless steels such as 304 also have been widely used as bipolar plates. Chung et al. [61] and Fukutsuka et al. [62] both utilized carbon-coated 304 SS in single-cell and three-cell PEM fuel cells, respectively. The first group employed chemical vapor deposition (CVD) to deposit a carbon film on Ni-coated 304 SS plates. Chemical stabilities comparable to Poco graphite were reported. The second group used plasma-assisted CVD to deposit a carbon layer on 304 SS. It was claimed that carbon-coated 304 SS exhibited higher electrical conductivity compared with uncoated 304 SS, while maintaining an acceptable level of corrosion resistance. As both studies were carried out for relatively short times, long-term experiments are required to justify the use of such materials as bipolar plates in PEM fuel cells.

Copper alloys also have been studied as potential candidates for bipolar plates in fuel cells. Good corrosion resistance of copper and its alloys in weakly corroding environments has been reported in the literature [63-66]. Nikam [66] examined the corrosion behavior of copper-beryllium alloy C-17200 using a Tafel extrapolation technique. It was noted that true corrosion representation cannot be obtained from such plots. Consequently, chronoamperometry was utilized to gain a better understanding by analyzing the corrosion products by employing SEM, EDS, and XPS. In an earlier work [63], the authors presented their findings on the resistivity of the corrosion layer of the above alloy using a four point probe apparatus in $0.5 \mathrm{M} \mathrm{H}_{2} \mathrm{SO}_{4}$ solution.
2.2.3. Bare Metals as Bipolar Plates. Stainless steel plates possess high thermal and electrical conductivities, mechanical strength, and reasonable manufacturing cost. Accordingly, uncoated stainless steel plates have been examined in both simulated and real fuel cell environments to evaluate their corrosion resistant behavior [25, 67-69]. Lafront et al. [67] studied the corrosion characteristics of untreated 316L SS plates in simulated anodic and cathodic PEMFC environments. They reported that the resulting passive films were unstable in a simulated anodic environment, but quite stable in a cathodic environment. The former was attributed to the onset of pitting corrosion due to the presence of hydrogen. Yang et al. [70] examined the corrosion resistance of bare 316L SS in simulated PEMFC environments containing $6 \times$ $10^{-4} \mathrm{M} \mathrm{F}^{-}$and different concentrations of sulfuric acid, ranging from $1 \times 10^{-5} \mathrm{M}$ to $1.00 \mathrm{M}$. Based on potentiostatic and potentiodynamic studies, it was concluded that the corrosion resistance of uncoated 316L SS decreases as the sulfuric acid concentration increases, leading to a decrease in the thickness of the passive film. Moreover, the ICR between 316L SS plates and the carbon substrate was claimed to decrease with increasing acid concentration. However, the reported ICR values for all acid concentrations at a compression force of $150 \mathrm{~N} \mathrm{~cm}^{-2}$ were higher than the US DOE target of $20 \mathrm{~m} \Omega \mathrm{cm}^{2}$. Ferritic stainless steels also have been considered as possible bipolar plate material; but, initially their ICR and corrosion resistant properties have been reported to be inferior to those of austenitic stainless steels [71]. More recently, however, it has been reported that the inclusion of small amounts of chromium can substantially improve the corrosion resistance of such plates in simulated and real PEMFC environments [72]. Kumagai et al. [72] conducted a series of experiments on ferritic stainless steel plates in simulated and real PEMFC environments. It was reported that by reducing the amounts of carbon and nitrogen and maintaining a minimum of $22 \mathrm{wt} \%$ chromium in the ferritic stainless steel plates, comparable performance in terms of corrosion resistance and ICR is observed. It was stated that bipolar plates containing $19 \mathrm{wt} \%$ chromium did not perform as well as plates with higher chromium contents. $\mathrm{X}$-ray fluorescence studies indicated contamination of the MEAs with iron species after $1000 \mathrm{~h}$ of operation in a real fuel cell, leading to lower fuel cell performance. The reported interfacial contact resistances of the ferritic stainless steel plates, however, were all higher than the DOE requirement (around $30 \mathrm{~m} \Omega \mathrm{cm}^{2}$ at a compaction force of $150 \mathrm{~N} \mathrm{~cm}^{-2}$ ).

Nikiforov et al. [73] examined the corrosion behavior of a number of commercially available stainless steels (AISI 316L, AISI 321, and AISI 347), Ni-based alloys (Inconel 625, Incoloy 825, and Hastelloy C-276), tantalum, and titanium for use in high-temperature steam electrolysers. All samples were exposed to an acidic medium containing $85 \%$ phosphoric acid at temperatures ranging from $30^{\circ} \mathrm{C}$ to $120^{\circ} \mathrm{C}$. It was reported that nickel-based alloys exhibited better corrosion resistance than austenitic stainless steel samples in the simulated environment at the temperatures studied. Amongst the stainless steel alloys, AISI 321 delivered the best results in terms of corrosion resistance at $120^{\circ} \mathrm{C}$. This is surprising since the molybdenum content of AISI $316 \mathrm{~L}$ 
is higher than that of AISI 321, and higher molybdenum content usually corresponds to higher corrosion resistance $[74,75]$. It was claimed that samples made from tantalum showed the best corrosion resistance while titanium samples exhibited the worst performance in the aforementioned simulated PEMFC environments.

Tian and Sun [76] investigated the electrochemical behavior of untreated high chromium (26wt\%) and nickel (19.4 wt\%) austenitic stainless steel (HCN) and 316L stainless steel $(16-18 \mathrm{wt} \% \mathrm{Cr}$ and $12-14 \mathrm{wt} \% \mathrm{Ni})$ plates in simulated anodic and cathodic PEMFC environments. The authors reported that $\mathrm{HCN}$ requires a lower passivation current density than 316L SS in both simulated environments. The above observation was ascribed to the higher $\mathrm{Cr}$ and $\mathrm{Ni}$ content of the former plates compared with that of the latter. Scanning electron microscopy revealed the presence of only uniform corrosion on the surface of $\mathrm{HCN}$ plates after potentiostatic polarization tests compared with that of 316L SS, where pitting corrosion also was noticed. Moreover, the ICR of the $\mathrm{HCN}$ plates was stated to be around $30 \mathrm{~m} \Omega \mathrm{cm}^{2}$ at a compaction pressure of $150 \mathrm{~N} \mathrm{~cm}^{-2}$ compared with a value of about $200 \mathrm{~m} \Omega \mathrm{cm}^{2}$ for bare 316L SS plates at the same compaction force. Although a marked decrease in ICR was reported, it is still higher than the target set by the US DOE. A summary of the above and several other studies [77-79] is presented in Table 1.

2.2.4. Coated Metallic Bipolar Plates. A wide variety of coatings and processes have been developed to address the concerns associated with bare metallic bipolar plates. A number of common coating materials for metallic bipolar plates is presented in Table 2. Such materials are often classified as carbon- and metal-based coatings. The former includes conductive polymers, graphite, diamond-like carbon and organic self-assembled monopolymers, while the latter comprises noble metals, metal carbides, and metal nitrides. Extensive research on both carbon- and metalbased coatings has been conducted and reported in the literature. It is generally agreed that such coatings must be conductive and adhere to the metallic bipolar plate substrate $[33,34,80]$. Proper adhesion to the substrate is achieved by careful selection of coating materials having thermal expansion coefficients similar to those of the substrate to minimize micro- and macrocrack formation. In an early report, Woodham et al. [81] investigated the roles of thermal expansion coefficient and corrosion resistance of a number of different bipolar plates on stack performance. Wind et al. [82] evaluated the performance of several bipolar plates, including bare 316 LS plates and plates coated with gold, in a real fuel cell environment for $100-1000 \mathrm{~h}$. The amount of $\mathrm{Fe}, \mathrm{Ni}$, and $\mathrm{Cr}$ ion contamination in the MEAs was determined after the operation of the fuel cell. The chemical analysis of the MEAs revealed that the amount of nickel and chromium ions was substantially reduced for gold-plated bipolar plates; however, the $\mathrm{Fe}^{3+}$ content in the MEA was considerably increased compared with that of base 316L SS bipolar plates. No explanation was provided; six other coatings also were evaluated, but their chemical nature and composition were not disclosed.

(1) Metal and Nonmetal Nitride Films. In an early study, Li et al. [97] examined the corrosion behavior and electrical conductivity of 316 SS plates coated with TiN. It was stated that both the corrosion resistance and the electrical conductivity of such plates were improved in simulated fuel cell environments similar to those of a real PEMFC. Significant long-term studies on the stability of such plates have yet to be reported. In another simulated PEM environment experiment, Wang et al. [98] investigated the electrochemical properties of $\mathrm{TiN}$ and $\mathrm{CrN}$ as coatings on a 316L SS substrate using electron beam physical vapor deposition. Their results showed promise for the $\mathrm{CrN}$-coated 316L SS used as an alternative bipolar plate material, with considerably fewer pinholes, and better interfacial contact resistance and corrosion protection than for the uncoated metal. Cho et al. [28] conducted long-term studies on the corrosion behavior of TiN-coated 316 SS plates and reported significant improvement when compared with uncoated 316 SS substrates. The authors have reported their findings in terms of surface energy, water contact angle and surface wettability. Water contact angles of $90^{\circ}$ and $60^{\circ}$, respectively, are reported for TiN-coated 316 SS and uncoated 316 SS plates. It is interesting to note that the water contact angle on TiN-coated 316 SS is similar to that of graphite; this has been confirmed by Taniguchi and Yasuda [99], who observed an increase in power output of a PEM fuel cell stack when gas flow channels showed low water wettability.

More recently, a large number of studies has been reported on metallic bipolar plates covered with various nitride films [84-86, 100-105]. Tian [84] reported improvement in both corrosion resistance and interfacial contact resistance of CrN/Cr-coated 316L SS compared with bare 316L SS bipolar plates in simulated PEMFC environments. A thin layer of pure chromium with a thickness of $0.5 \mu \mathrm{m}$ was first deposited on 316L SS followed by a dense CrN coating of about $4 \mu \mathrm{m}$ thickness using a physical vapor deposition (PVD) technique.

A passive current density of less than $10 \times 10^{-6} \mathrm{~A} \mathrm{~cm}^{-2}$ in a simulated PEMFC environment consisting of $0.05 \mathrm{M}$ $\mathrm{H}_{2} \mathrm{SO}_{4}$ and $2 \mathrm{ppm} \mathrm{F}^{-}$operating at $70^{\circ} \mathrm{C}$ was reported; this is about one order of magnitude lower than that for bare 316L SS. Furthermore, the ICR for the $\mathrm{CrN} / \mathrm{Cr}$ coated 316L SS was reported to be about $30 \mathrm{~m} \Omega \mathrm{cm}^{2}$ at a compaction force of $150 \mathrm{~N} \mathrm{~cm}^{-2}$, while that for the corresponding bare $316 \mathrm{~L}$ SS was more than three times as great at $100 \mathrm{~m} \Omega \mathrm{cm}^{2}$. The higher ICR of the bare 316L SS plates was attributed to the formation of a natural air-formed oxide film on the plate surface, resulting in lower conductivity. Cha et al. [100] investigated the corrosion resistance and ICR properties of nitride films as protective layers for austenite 304 stainless steel bipolar plates. The plates were coated with $\mathrm{NbN}$ singlephase or $\mathrm{NbN} / \mathrm{NbCrN}$ multiphase films using inductively coupled plasma-assisted D.C. magnetron sputtering system. Polarization tests were carried out in a conventional threeelectrode cell using a solution of $0.5 \mathrm{M} \mathrm{H}_{2} \mathrm{SO}_{4}$ and $2 \mathrm{ppm}$ 


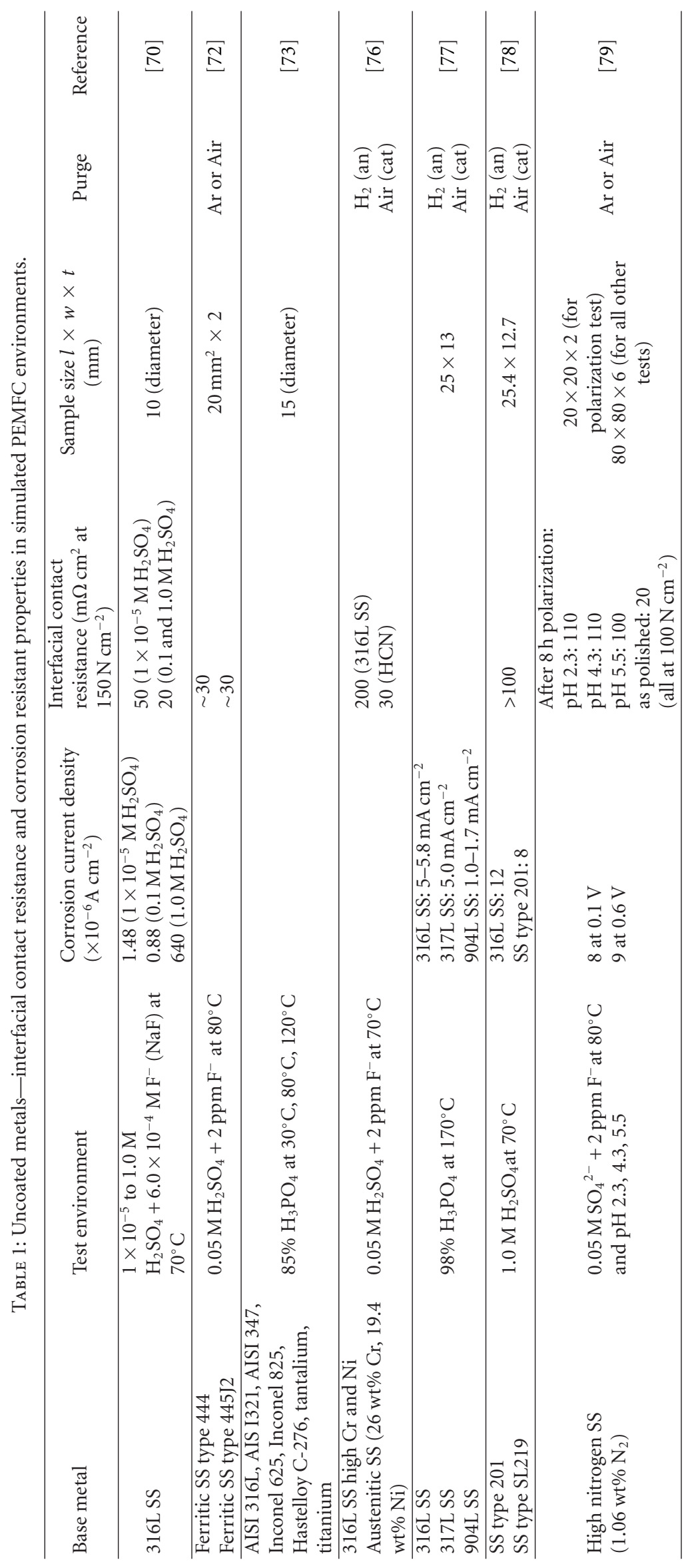


TABLe 2: Potential coating materials for metallic bipolar plates.

\begin{tabular}{|c|c|c|c|c|c|}
\hline \multirow{2}{*}{ Coating } & \multicolumn{4}{|c|}{ Base plate material } & \multirow{2}{*}{ Reference } \\
\hline & Aluminum & Stainless steel & Titanium & Nickel & \\
\hline Conductive polymer & $\bullet$ & & & & [33] \\
\hline Chromium & & - & & & {$[83]$} \\
\hline Chromium nitride & & - & & & [84-87] \\
\hline Diamond-like carbon & - & & & & {$[33]$} \\
\hline Gold & - & & • & & {$[81,82]$} \\
\hline Gold-titanium & & - & & & {$[88]$} \\
\hline Gold-nickel & & - & & & {$[88]$} \\
\hline Graphite foil & - & & - & - & [89] \\
\hline Graphite topcoat & - & - & - & - & [89] \\
\hline Indium tin oxide & - & & & & {$[90]$} \\
\hline Lead oxide & & - & & & [90] \\
\hline Nickel & & - & & & {$[91]$} \\
\hline Niobium & & - & & & [92] \\
\hline Organic monopolymer & - & & & & [33] \\
\hline Platinum & & & - & & {$[88,93,94]$} \\
\hline Silicon carbide & & - & & & {$[90]$} \\
\hline Silver & & - & & & {$[91]$} \\
\hline Silver-PTFE & & • & & & [95] \\
\hline Titanium-aluminum & - & & & & [90] \\
\hline Titanium nitride oxide & & - & & & [90] \\
\hline Zirconia & & • & & & [96] \\
\hline
\end{tabular}

$\mathrm{HF}$ as the electrolyte at $70^{\circ} \mathrm{C}$ with no gas purging during the experiments. A corrosion current density of $9.87 \times$ $10^{-9} \mathrm{~A} \mathrm{~cm}^{-2}$ (at a corrosion potential of $-0.48 \mathrm{~V}$ versus SCE) was reported for the multiphase $\mathrm{NbN} / \mathrm{NbCrN}$ film with a $\mathrm{Cr}$ target power and gas ratio of $300 \mathrm{~W}$ and 0.2 , respectively. On the other hand, the best result for the single-phase $\mathrm{NbN}$ film was obtained with a $\mathrm{Cr}$ target power and gas ratio of $150 \mathrm{~W}$ and 0.4 , respectively; with a corresponding corrosion current density of $8.26 \times 10^{-9} \mathrm{~A} \mathrm{~cm}^{-2}$ (at a corrosion potential of $-0.12 \mathrm{~V}$ versus SCE) reported. These are significant improvements over bare 304 stainless steel plates, where the corrosion current density under similar experimental conditions was stated to be several orders of magnitude higher at $1.3 \times 10^{-5} \mathrm{~A} \mathrm{~cm}^{-2}$ (at a corrosion potential of $-0.79 \mathrm{~V}$ versus SCE). However, the reported ICR values for all the coated samples were much higher than the target value set by U.S. DOE. The best ICR result was claimed for the $\mathrm{NbN}$ film prepared at a $\mathrm{Cr}$ target power of $150 \mathrm{~W}$ and gas ratio of 0.40 ; this film had a value of $35 \mathrm{~m} \Omega \mathrm{cm}^{2}$ at a compaction pressure of $150 \mathrm{MPa}$ (about 150\% higher than the U.S. DOE target at the same compaction force). Although substantial improvement in the corrosion resistance of the above coated plates were reported, their ICR was significantly higher than the acceptable levels.

Zhang et al. [101] examined the influence of a chromium-based multilayer deposited on 304 SS plates in terms of its corrosion resistance and ICR properties. The resulting multilayer- $\mathrm{Cr}_{3} \mathrm{Ni}_{2} / \mathrm{Cr}_{2} \mathrm{~N} / \mathrm{CrN}$-was deposited on polished 304 SS plates using a magnetron sputtering technique at a constant temperature of $473 \mathrm{~K}$ and varying gas pressures. Although the initial corrosion current density of the coated 304 SS plate was lower than that of the bare 304 SS in a simulated environment, its performance after 8 hours at $600 \mathrm{mV}$ was somewhat similar to that of the bare 304 SS plates. This may be attributed to the passivation of the untreated 304 SS plates after several hours of contact with the electrolyte. Furthermore, the ICR of the coated 304 SS plate was reported to be comparable to that of graphite (approximately $15 \mathrm{~m} \Omega \mathrm{cm}^{2}$ ), while that of the bare 304 SS was claimed to be in the neighborhood of $110 \mathrm{~m} \Omega \mathrm{cm}^{2}$, due to oxide layer formation on its surface. Zhang et al. [102] investigated the performance of arc ion plated $\mathrm{Cr} / \mathrm{CrN} / \mathrm{Cr}$ multilayers on 316L SS plates in simulated PEMFC environments containing $0.5 \mathrm{M} \mathrm{H}_{2} \mathrm{SO}_{4}$ and $2 \mathrm{ppm} \mathrm{\textrm {F } ^ { - }}$ at $70^{\circ} \mathrm{C}$. The corrosion current density of the coated 316L SS plate in the aforementioned simulated anodic environment was reported to be about two orders of magnitude lower than that of the bare 316L SS. Although the initial corrosion current density was reported to be relatively low, long-term studies need to be conducted to determine any adverse effects of the gradual dissolution of the top layer; that is, chromium, which is known to take place in harsh acidic environments. Furthermore, the ICR of the coated samples was claimed to vary between 30 and $35 \mathrm{~m} \Omega \mathrm{cm}^{2}$ at a compaction pressure of $150 \mathrm{~N} \mathrm{~cm}^{-2}$, which is still $50 \%$ to $80 \%$ higher than the US DOE 2015 target. The authors concluded that the top layer (chromium layer in contact with GDL) must be modified to avoid contamination of both catalyst layers and the proton exchange membrane. 
Hong et al. [85] attempted to fabricate coated AISI $316 \mathrm{~L}$ plates with low ICR and high corrosion resistance by employing a high-density plasma nitriding process using a gas mixture of nitrogen and hydrogen at temperatures ranging from 530 to $650 \mathrm{~K}$. The corrosion resistance of the coated samples was measured in a simulated environment containing $0.1 \mathrm{~N} \mathrm{H}_{2} \mathrm{SO}_{4}$ and $2 \mathrm{ppm} \mathrm{HF}$ solution at $80^{\circ} \mathrm{C}$. The corrosion current density (at $0.6 \mathrm{~V}$ ) of the coated samples was reported to increase as the nitriding temperature increased from 530 to $650 \mathrm{~K}$, ranging from 3.43 to $7.57 \times$ $10^{-6} \mathrm{~A} \mathrm{~cm}^{-2}$. The improvement in corrosion resistance of the coated samples was attributed to the formation of a dense Sphase without chromium-depleted regions. The ICR value of the treated samples was reported to increase as the nitriding temperature increased from 530 to $650 \mathrm{~K}$. The ICR value for the bare sample at a compaction pressure of $150 \mathrm{~N} \mathrm{~cm}^{-2}$ was stated to be $82 \mathrm{~m} \Omega \mathrm{cm}^{2}$, while the corresponding values for the samples nitrided at 530,590 , and $650 \mathrm{~K}$ were reported to be 40,13 , and $11 \mathrm{~m} \Omega \mathrm{cm}^{2}$, respectively. The improvement in the electrical conductivity of the treated samples was claimed to be the result of the formation of chromium nitrides on the surface of the treated samples, as well as suppressed oxide formation due to the nitriding process. The sample nitrided at $590 \mathrm{~K}$ was reported to have superior electrical and electrochemical properties. Han et al. [86] examined the ICR and corrosion resistance of nitrided Cr-electroplated AISI 316L stainless steel plates using inductively coupled plasma at a constant ICP power of $400 \mathrm{~W}$ while varying the substrate dc bias voltage from -100 to $-300 \mathrm{~V}$. It was reported that after the plasma nitriding, all samples exhibited uniform and crack-free chromium nitride layers, but with different thicknesses and surface morphologies. Moreover, it was claimed that the ICR of the samples decreased with increasing dc bias voltage, with samples prepared at the highest dc bias voltage $(-300 \mathrm{~V})$ showing the lowest ICR value of $5.6 \mathrm{~m} \Omega \mathrm{cm}^{2}$. This was attributed to the formation of nanosized protrusions at the surface of the nitrided samples, resulting in the expansion of the contact points or areas between the bipolar plate and the gas diffuser. Lastly, based on potentiodynamic polarization measurements, it was concluded that all the treated samples had acceptable corrosion resistance in both simulated anodic and cathodic PEMFC environments. However, this last conclusion was drawn based on potentiostatic test lasting for less than three hours; it is imperative to carry out such tests for much longer periods to substantiate such claims.

Choi et al. [103] investigated the electrochemical and electrical properties of $(\mathrm{Ti}, \mathrm{Cr}) \mathrm{N}_{x}$ coatings on $316 \mathrm{~L}$ SS deposited by ICR-ARMS, using a gas mixture of argon and nitrogen. Corrosion experiments were performed in a simulated environment containing $0.05 \mathrm{M} \mathrm{H}_{2} \mathrm{SO}_{4}$ and $2 \mathrm{ppm}$ $\mathrm{HF}$ at $80^{\circ} \mathrm{C}$. The primary variable was the nitrogen gas flow rate during the sputtering deposition. The anodic and cathodic corrosion current densities at $0.60 \mathrm{~V}$ were reported to be $5 \times 10^{-8} \mathrm{~A} \mathrm{~cm}^{-2}$ and $5 \times 10^{-7} \mathrm{~A} \mathrm{~cm}^{-2}$, respectively. The interfacial contact resistance of the coated plates fabricated with a nitrogen gas flow rate of $3.0 \mathrm{sccm}$ (standard cubic centimeters per minute) was reported to be $4.5 \mathrm{~m} \Omega \mathrm{cm}^{2}$ at a compaction pressure of $150 \mathrm{~N} \mathrm{~cm}^{-2}$.
Although most of the studies on coatings for metallic plates have resulted in positive outcomes in terms of interfacial contact resistance and corrosion resistance properties of the resultant layers, there have been a number of reports on the inadequacy of such layers in fuel cell environments. Barranco et al. [104] evaluated the electrical properties and corrosion resistance of chromium nitride-coated aluminum alloy Magnal-45 plates in a simulated PEMFC environment. All aluminum alloy plates were coated with $\mathrm{CrN}$ single layers of different thicknesses, ranging from $3 \mu \mathrm{m}$ to $5 \mu \mathrm{m}$, utilizing a cathodic arc evaporation physical vapor deposition (CAE-PVD) technique. At a compaction force of $135 \mathrm{~N} \mathrm{~cm}^{-2}$, samples coated with $\mathrm{CrN}$ layer thicknesses of 3 and $4 \mu \mathrm{m}$ exhibited similar ICR values of 8 and $8.5 \mathrm{~m} \Omega \mathrm{cm}^{2}$, respectively, while the coated samples with a $\mathrm{CrN}$ thickness of $5 \mu \mathrm{m}$ generated the lowest contact resistant $\left(6 \mathrm{~m} \Omega \mathrm{cm}^{2}\right)$. The ICR for bare aluminum alloy at the same compaction force was reported to be $34 \mathrm{~m} \Omega \mathrm{cm}^{2}$. Although significant reduction in the corrosion current density of coated samples in simulated PEMFC environments was observed compared with bare aluminum alloy plates, similar corrosion behavior was reported for coated samples as was observed for untreated plates. Such behavior was attributed to the presence of surface defects, such as pitting holes. The authors concluded that unless the formation of pitting holes is eliminated, the utilization of $\mathrm{CrN}$-coated aluminum alloy plates may not be a viable option in aggressive fuel cell environments.

Brady et al. [105] developed a preferential thermal nitridation process in which a nickel-chromium alloy was coated with a thin layer of $\mathrm{CrN} / \mathrm{Cr}_{2} \mathrm{~N}$. Based on their observations, a defect- and pinhole-free coating can be achieved with excellent corrosion resistance and negligible interfacial contact resistance. Another substrate, 446 SS, also has been tested with positive outcomes in terms of corrosion and contact resistance. Lee et al. [106] employed a low-temperature thermal nitridation technique to deposit a $130 \mathrm{~nm}$-thick layer of Cr-nitride/oxide on the surface of this steel and found improvements in electrical conductivity (over the base metal) with no increase in interfacial contact resistance.

(2) Chromium-Containing Films. In recent years, chromium-nitrogen films as a coating material for stainless steel plates have received some attention. According to $\mathrm{Fu}$ et al. [107], 316L SS plates coated with $\mathrm{Cr}_{0.49} \mathrm{~N}_{0.51}$ delivered the best result in terms of interfacial conductivity and corrosion resistance and exhibited high surface energy. Cho et al. [83] applied a dense layer of chromium on 316L austenitic stainless steel by pack cementation at $1100^{\circ} \mathrm{C}$ for several time periods, ranging from 2.5 to 10 hours. At short time periods; that is, less than 5 hours, improvements in corrosion resistance were reported. However, for longer running times; that is, greater than 5 hours, no significant improvements were observed. Feng et al. [108] used ion implantation of various $\mathrm{Ni}-\mathrm{Cr}$ coatings onto 316 L SS to test the conductivity and interfacial contact resistance of such bipolar plates. The ICR results showed an elevenfold decrease 
in interfacial contact resistance for $\mathrm{Ni}$-Cr-coated plates compared with uncoated 316L SS plates: from $255.4 \mathrm{~m} \Omega \mathrm{cm}^{2}$ to $22.1 \mathrm{~m} \Omega \mathrm{cm}^{2}$, respectively.

$\mathrm{Wu}$ et al. [109] examined the corrosion resistance and interfacial contact resistance of chromium-containing carbon films on unpolished 316L SS plates in simulated PEMFC environments containing $0.5 \mathrm{M} \mathrm{H}_{2} \mathrm{SO}_{4}$ and $5 \mathrm{ppm}$ $\mathrm{F}^{-}$. Six carbon-chromium films with different chemical compositions, ranging from $5 \mathrm{wt} \%$ to $23 \mathrm{wt} \%$ chromium, were deposited on stainless steel plates using pulsed bias arc ion plating (PBAIP). It was claimed that the film with the highest chromium content; that is, $23 \mathrm{wt} \% \mathrm{Cr}$ and $77 \mathrm{wt} \% \mathrm{C}$, exhibited the best corrosion resistance in the PEMFC simulated environment at both $25^{\circ} \mathrm{C}$ and $70^{\circ} \mathrm{C}$. A corrosion current density of $9.1 \times 10^{-8} \mathrm{~A} \mathrm{~cm}^{-2}$ at $0.6 \mathrm{~V}$ (versus $\mathrm{SCE}$ ) and $25^{\circ} \mathrm{C}$ was reported for the above film; this is two orders of magnitude lower than that of bare $316 \mathrm{~L} \mathrm{SS}\left(1.6 \times 10^{-5} \mathrm{~A} \mathrm{~cm}^{-2}\right.$ at $\left.0.6 \mathrm{~V}\right)$. The corrosion current density of the treated plate increased more significantly than that for bare 316L SS when the temperature of the system increased from $25^{\circ} \mathrm{C}$ to $70^{\circ} \mathrm{C}$. The lowest ICR value$2.8 \mathrm{~m} \Omega \mathrm{cm}^{2}$ at a compaction pressure of $150 \mathrm{~N} \mathrm{~cm}^{-2}$-was reported for the above sample as well $(23 \mathrm{wt} \% \mathrm{Cr}$ and $77 \mathrm{wt} \%$ C). The observed improvement in ICR was attributed to the high carbon content of the deposited film, which was reported to be primarily amorphous. ICR values of the above sample after corrosion testing were reported to increase by about $200 \%$ and $300 \%$ in the simulated anodic and cathodic environments, respectively. The increase in ICR for the above plates was explained in terms of pitting corrosion by examining the surface morphology of the sample before and after corrosion tests.

In an earlier paper, the same authors [87] conducted a series of experiments on chromium nitride films deposited on 316L SS plates using PBAIP. The nitrogen content of the deposited films was increased from 0.28 at.\% to 0.50 at.\% by varying the nitrogen flow rate during sputter deposition from 20 to $80 \mathrm{sccm}$. The phase structure and chemical composition of the resulting films were examined by Xray diffractometry and X-ray photoelectron spectroscopy. It was reported that the multiple-phase structure of chromium nitride films deposited at low nitrogen flow rates changed into single phase $\mathrm{CrN}$ at high nitrogen flow rates, resulting in more corrosion-resistant films in simulated PEMFC environments. The superiority of the chromium nitride films with higher nitrogen content was attributed to the existence of a more uniform film, which is less susceptible to corrosion, since the difference in corrosion potential of various phases can lead to the formation of local electrochemical cells, accelerating the corrosion rate of such samples.

Lee et al. [110] performed a series of experiments on $316 \mathrm{~L}$ SS plates treated with a powder mix containing $25 \mathrm{wt} \%$ to $50 \mathrm{wt} \%$ chromium. Surface treatment was carried out at a constant temperature of $1050^{\circ} \mathrm{C}$ in an argon atmosphere for 2.5 to 23 hours. Potentiodynamic and potentiostatic tests revealed the corrosion resistant superiority of the treated 316L SS in a simulated PEMFC environment compared with that of bare 316L SS. The ICR of the chromized sample with the lower $\mathrm{Cr}$ content in the original powder mix and longer treatment time; that is, $25 \mathrm{wt} \% \mathrm{Cr}$ and $23 \mathrm{~h}$ of cementation, was reported to be even higher than that for bare 316L SS. This was attributed to the formation of a thicker oxide layer after the heat treatment and the reduction in the chromium carbide content in the resulting layer. Auger electron spectroscopy verified the presence of excess $\mathrm{Cr}$ in the coating layer for the sample with the longer heat treatment period; this is in agreement with an earlier report, where the excess $\mathrm{Cr}$ in the coating layer was ascribed to a higher ICR [71].

More recently, Tian [84] fabricated a series of 316L SS bipolar plates coated with a thin layer of chromium nitride using physical vapour deposition. Corrosion resistance and interfacial contact resistance experiments showed better performance compared with 316L SS plates with air-formed oxide films. The ICR of the former was reported to be as low as one-third of the latter at a compaction force of $150 \mathrm{~N}$ $\mathrm{cm}^{-2}$. It is imperative to note that although $\mathrm{CrN}$-coated stainless steel plates exhibit higher corrosion resistance in reducing and oxidizing environments, the presence of any pinholes or microcracks in the $\mathrm{CrN}$ film will initiate and enhance local corrosion, leading to performance loss and cell degradation.

(3) Noble and Nonnoble Metal Coatings. Noble metals such as gold, platinum, and platinum-group metals and alloys also have been used to coat stainless steel $[33,34,111]$ and titanium $[88,93,94]$ to improve their chemical and other properties in harsh environments similar to those of PEM fuel cells. However, such metals are prohibitively expensive and often thicker layers are needed to provide adequate corrosion resistance of the base metal in acidic environments. Nevertheless, the greatest level of success that has been reported on metal bipolar plates has been achieved with noble metal coatings. Wang et al. [93] examined gold-plated titanium bipolar plates in a single cell with a $25 \mathrm{~cm}^{2}$ active area. A proprietary method was used to deposit gold coatings of $2.5 \mu \mathrm{m}$ thickness onto titanium plates. Polarization curves for graphite, pure titanium, and titanium coated with gold were presented at several different cell temperatures, ranging from 40 to $80^{\circ} \mathrm{C}$. Gold-plated titanium plates performed poorly when the fuel cell temperature increased from 40 to $60^{\circ} \mathrm{C}$. However, a significant improvement was reported at higher cell temperatures of 80 to $90^{\circ} \mathrm{C}$. In a paper published earlier by the same group [94], three different types of metallic bipolar plates were examined: pure titanium, titanium sintered with iridium oxide, and titanium coated with platinum. Titanium plates coated with platinum delivered the best result when tested in a single PEM fuel cell operated at cell temperatures of $50-65^{\circ} \mathrm{C}$. The effects of electropolishing and gold-titanium and gold-nickel coating on 316L SS bipolar plates were investigated and compared to mechanically polished plates by Yun [88], who found that by electropolishing the steel plates using electron beam radiation, a very uniform and smooth surface morphology free of lumps and crevices was obtained, and that the plates exhibited markedly low electrical resistance. Furthermore, the coatings were effective 
at inhibiting corrosion, unlike the mechanically polished plates, which underwent significant degradation. Jung et al. [112] studied the electrochemical deposition of platinum onto a titanium bipolar plate in a unitized regenerative fuel cell (URFC). They reported that the deposition of platinum on titanium bipolar plates effectively inhibits the formation of the oxide layer and the corrosion of the titanium surface. This led to decreased contact resistance and good stability for long-term operation. To improve the adhesion of the Pt coating, an acidic treatment was employed and the Pt-coated plates showed no signs of corrosion.

Yoon et al. [113] experimented with several coating combinations, including gold at various thicknesses, titanium, zirconium, zirconium nitride, zirconium niobium, and zirconium nitride with a gold top layer. Testing for corrosion resistance, it was reported that only the zirconium coated sample met the DOE goals for both anode and cathode type environments. Contact resistance testing also was carried out and it was found that thin $(2 \mathrm{~nm})$ gold coatings can reduce contact resistance. But, admittedly, such coatings and processes are not cost effective. Feng et al. [91] evaluated the electrical and electrochemical properties of silver-implanted 316L SS plates in a simulated PEMFC cathode environment with $0.5 \mathrm{M} \mathrm{H}_{2} \mathrm{SO}_{4}$ and $2 \mathrm{ppm} \mathrm{HF}$ at $80^{\circ} \mathrm{C}$. It was observed that silver implantation decreases the thickness of the passive layer from 3 to $2 \mathrm{~nm}$, resulting in higher electrical conductivity. Moreover, the corrosion current density of the treated plate was claimed to decrease to $2.0 \times 10^{-6} \mathrm{~A} \mathrm{~cm}^{-2}$ from $17.7 \times 10^{-6} \mathrm{~A} \mathrm{~cm}^{-2}$ for that of the bare 316L SS plate. Silver ion implantation also was reported to significantly decrease the ICR of $316 \mathrm{~L}$ SS (to about $150 \mathrm{~m} \Omega \mathrm{cm}^{2}$ ) compared with that of the bare 316L SS plates (around $430 \mathrm{~m} \Omega \mathrm{cm}^{2}$ ) at a compaction force of $150 \mathrm{~N} \mathrm{~cm}^{-2}$. This reduction in the ICR was attributed to the precipitated silver nanoparticles in the implanted layer as well as a noticeable reduction in the passive layer thickness and increased amounts of highly conducive metallic silver and nickel. Feng et al. [114] determined the impact of a nickel-rich layer with a thickness of about $100 \mu \mathrm{m}$ deposited on 316L SS by ion implantation. All tests showed higher chemical stability of such plates in accelerated cathode environments containing $0.5 \mathrm{M} \mathrm{H}_{2} \mathrm{SO}_{4}$ with $2 \mathrm{ppm} \mathrm{HF}$ at $80^{\circ} \mathrm{C}$. The superiority of $\mathrm{Ni}$-coated plates is attributed to the reduction in the thickness of the passive layer caused by the $\mathrm{Ni}$ implantation. Lee et al. [96] investigated the viability of a zirconia coating on 316L SS plates in a simulated PEMFC environment. The zirconia coating was applied by employing a sol-gel dip coating method followed by calcination at $800^{\circ} \mathrm{C}$ for an hour. Although the corrosion resistance of the zirconia-coated 316L SS was reported to improve by one order of magnitude compared with that of the bare 316L SS plate in a simulated PEMFC environment, the resulting layer exhibited a high ICR at a compaction force of $150 \mathrm{~N} \mathrm{~cm}^{-2}$ that was about three times higher than the untreated $316 \mathrm{~L}$ SS sample. It was suggested to modify the zirconia film by inclusion of conducting materials into the coating via doping to improve its electrical conductivity. Such measures have resulted in films with lower ICR in earlier studies [115-117].
(4) Composite, Conductive Polymers, and Carbon-Based Coatings. Composite films have been developed and applied to stainless steel bipolar plates to improve their corrosion resistance and interfacial contact resistance. Fu et al. [95] electrodeposited an Ag-polytetrafluoroethylene composite layer on 316L SS bipolar plates and reported that the plates exhibited lower interfacial contact resistance, higher corrosion resistance, and better hydrophobic characteristics. Novel composite bipolar plates based on 316L SS also have been investigated. Kuo and Chen [118] fabricated bipolar plates using 316L SS and Nylon-6 polymer thermoplastic matrix using an injection molding process. It was claimed that such bipolar plates are relatively lightweight, easy to process, inexpensive, and exhibit favourable gas tightness, hardness and corrosion resistance. However, they failed to match graphite bipolar plates as far as stack performance was concerned.

Joseph et al. [57] investigated the viability of conductive polymer coatings such as polyaniline (PANI) and polypyrrole (PPY) on 304 SS. They reported superior corrosion behavior and acceptable interfacial contact resistance. However, longterm economic viability and durability studies are absent from this report. Wang and Northwood [119] developed a method to electro-polymerize polypyrrole films on 316L SS using both galvanostatic and cyclic voltammetric methods. The aforementioned electrochemical methods yielded two different films with marked differences in morphology. Optical microscopy revealed less intergranular corrosion for plates covered with a dense coat of polypyrrole when compared with untreated 316L SS plates.

Physical vapor deposition was employed by Lee et al. [120] on two base metals, namely, 316L SS and 5052 aluminum alloy, with a YZU001-like diamond film. Tafel extrapolations from polarization curves were used to compare the corrosion rates of the above metal plates with that of graphite. Surprisingly, the metallic plates outperformed graphite plates when placed in a single cell to measure interfacial contact resistance and performance. According to the authors, 316L SS plates exhibited better corrosion resistance with the above coating than aluminum plates. However, aluminum plates proved to be superior compared with stainless steels when interfacial contact resistance was concerned, although they had a shorter life when tested in a single cell. Fu et al. [121] investigated the electrical and electrochemical properties of three different types of carbonbased films on 316L stainless steel plates in simulated PEMFC environments. All three films-pure carbon, C-Cr, and C$\mathrm{Cr}-\mathrm{N}$ composite films - were prepared using pulsed bias arc ion plating. At $2160 \mathrm{~m} \Omega \mathrm{cm}^{2}$ and $555 \mathrm{~m} \Omega \mathrm{cm}^{2}$, respectively, the ICR values of the pure carbon film and the C-Cr$\mathrm{N}$ composite were reported to be significantly higher than that set by the US DOE at a compaction force of $1.5 \mathrm{MPa}$. However, the bipolar plate with the $\mathrm{C}-\mathrm{Cr}$ composite film exhibited an acceptable ICR value of about $8.72 \mathrm{~m} \Omega \mathrm{cm}^{2}$ at the same compaction force. The corrosion current density of the plate covered with the C-Cr composite film was reported to be two orders of magnitude lower than that of the bare 316L SS in simulated anode and cathode PEMFC 
environments. However, the corrosion current density for the other two carbon-based films was not disclosed.

2.2.5. Fabrication of Metallic Bipolar Plates. There has been significant activity in fabricating bipolar plates using a number of different processes. It is necessary to develop a manufacturing process that is cost effective and efficient in order to make a metallic plate a viable candidate for commercial production. The key manufacturing processes involved in the fabrication of metal plates include forming thin plates with appropriate flow fields, welding of the anode and the cathode plates, and coating of the metal substrate. Commonly used forming processes include compression molding, stamping, and embossing; the common defects that result from such processes are warping, distortion, and cracking [38]. Metallic plates have extensively been fabricated and tested for their corrosion resistance and interfacial contact resistance properties [122-127].

Dundar et al. [128] investigated the effects of stamping and hydroforming on the corrosion resistance of metallic bipolar plates. Microchannel arrays were fabricated on 304 SS having an initial thickness of $51 \mu \mathrm{m}$ and the plates tested using potentiodynamic and potentiostatic techniques. An initial flat blank also was tested for reference to simulate the PEMFC environment; $0.5 \mathrm{M} \mathrm{H}_{2} \mathrm{SO}_{4}$ solution was used as the working electrolyte and the temperature was maintained at $80^{\circ} \mathrm{C}$. A stamping force, ranging from 100 to $300 \mathrm{kN}$, and a hydroforming pressure range of $20-60 \mathrm{MPa}$ were considered along with a stamping speed of $0.1-1 \mathrm{~mm} \mathrm{~s}^{-1}$. It was found that the corrosion current increased with increasing stamping force, while pressure had only a minor effect. The corrosion resistance of the blank plate was better than that of the hydroformed plate (except when the plate was hydroformed at $60 \mathrm{MPa}$ ), but worse than that of stamped plates (except when the plate was stamped at $300 \mathrm{kN}$ ). It also was reported that faster stamping speed resulted in an improvement in the corrosion resistance of the plates.

Peng et al. [129] investigated the feasibility and optimization of flow channels for hydroformed bipolar plates. Significant cost reductions were reported when machining the flow channels was replaced with the hydroforming process. Liu and Hua [130] investigated the rubber pad forming process to fabricate metallic bipolar plates $(82 \mathrm{~mm}$ $\times 75 \mathrm{~mm}$ ) for PEM fuel cells. They reported that employing the above technique can result in bipolar plates with high surface quality and dimensional accuracy, and low cost and high efficiency. Additionally, the key process parameters of the rubber pad method were investigated and a prototype was fabricated to validate the accuracy and reliability of the simulations. The estimated fabrication cost of a double bipolar plate with noncoated 304 SS was reported to be approximately $\$ 1.9$; however, the useful life of the rubber pad is relatively short.

Yu et al. [131] developed a new technique based on asymmetric composite endplates with a precurvature, and reported improved pressure distribution in the stack. In another study, the same authors [132] devised a new axiomatic design to fabricate composite PEMFC endplates for transportation applications. Based on a number of bending and thermal conductivity tests, they claimed that the flexural strength and stiffness of a carbon fiber epoxy structure with polyurethane foam- (PUF-) filled honeycomb was three times greater than those of other structures. Furthermore, inserts were used to reinforce the composite structure to prevent deformation during clamping. Nikam and Reddy [133] reported on the use of corrugated metal for fabricating bipolar plates, with a focus on weight and cost reduction. By replacing traditional machined parallelflow channels with sheet metallic bipolar plates, significant savings in both weight and cost were noted. Yi et al. [134] studied the effects on fuel cell performance of a wave-like flow field and a perforated design for end and bipolar plates, respectively. Improvements in both volumetric and specific power densities were observed; however, challenges with adequate stack cooling were encountered.

A large number of coating processes and techniques has been employed both in the research community and in industry to deposit a wide array of coating materials on different base materials. Pulse current electrodeposition has been successfully used to apply a thin layer of gold over aluminum bipolar plates [135, 136]. Painting and pressing have been employed to apply a graphite layer onto aluminum, titanium, and nickel bipolar plates [89], while electron beam evaporation has been used to deposit a thin layer of indium-doped tin oxide on a number of base metals such as stainless steel [90]. Physical vapor deposition has been employed to deposit a number of coating materials such as chromium or nickel-phosphorus alloy onto aluminum, stainless steel and titanium [137]. Vapor deposition and sputtering have been reported to deliver excellent results when lead oxide was deposited onto stainless steel bipolar plates $[90,138]$.

In summary, fabrication methods must not significantly contribute to the overall resistance of the bipolar plate. Most studies have focused on the electrical resistance of bipolar plates with emphasis on the composition of the materials under investigation; however, this may not be the only contributing factor in an operational fuel cell. The contact resistance between the bipolar plate material and the gas diffusion layer (GDL) also can have a significant influence on the overall resistance. Accordingly, flow field design and the corresponding fabrication method can play a major role in lowering the overall resistance of such plates. Moreover, thermal management in most PEM fuel cell stacks becomes critical, necessitating the incorporation of cooling channels into the design and fabrication of bipolar plates. It is common practice to fabricate two half-plates with flow-field channels on the front side and cooling channels on the back side, followed by a joining method to connect them together. The selection of an appropriate joining technique is crucial since it can potentially contribute to significant internal contact resistance. This is a pressing issue in the fabrication of composite bipolar plates where such plates are often pressed together to create a single bipolar plate. However, in the case of metallic bipolar plates, the use of appropriate joining techniques such as laser welding can significantly lower the inner contact resistance [139]. A summary of the above 
studies and several other works [92, 140-144] is presented in Table 3.

\section{Critical Analyses}

3.1. Bare Metals as Bipolar Plates. Due to its low cost and favourable physical and chemical properties, stainless steel has become the primary candidate for bipolar plate construction. The formation of a passive oxide layer protects the plate from corrosion, but leads to higher interfacial contact resistance. The formation of this passive layer is dependent upon the nature and chemical composition of the alloy. It is generally agreed that the higher the chromium content, the higher the corrosion resistance. However, the influence of other elements such as nickel and molybdenum on passive film formation and, consequently, on corrosion resistance and interfacial contact resistance must be taken into consideration. Pitting resistance equivalent (PRE) can be employed to rank different iron-based metals for use in fuel cells. It is important to point out that ICR and corrosion resistant tests performed in simulated PEM environments must be carried out at high temperatures $\left(60-90^{\circ} \mathrm{C}\right)$ and long periods (several hundreds or even thousands of hours), resembling real fuel cell environments. When exposed to harsh environments, the thickness of the passive layer formed on many metals may change with time. In addition, the corrosion rate of stainless steel increases as operating temperature rises. Therefore, it is imperative to conduct both simulated and real tests at elevated temperatures and extended time periods to ensure the accuracy and validity of the drawn conclusions. Furthermore, there has been disagreement among various groups on the relationship between alloying content, corrosion and contact resistance behavior of different stainless steel bipolar plates [52, 53, 55]. Future work should attempt to establish a benchmark for alloying content and its effect on corrosion resistance and ICR of candidate metals.

3.2. Surface Treatments and Coatings. There are a limited number of materials exhibiting a combination of high corrosion resistance and low interfacial contact resistance for use in PEM fuel cells. Furthermore, many of these metals are rare and prohibitively expensive. As a result, the search for surface treatments of inexpensive and widely available metals that are capable of enhancing their performance in fuel cell environments is well established and underway. Surface modification techniques, including electrochemical surface treatment, carburization, thermal nitriding, low temperature plasma nitriding and ion implantation, have been extensively investigated. Most electrochemical surface treatments involve the modification of the oxide layer by decreasing its thickness or enriching its chromium content, leading to higher corrosion resistance and lower ICR. The type of electrolyte used in such processes needs to be carefully selected to avoid the incorporation of unwanted elements and compounds into the passive layer or diminish the concentration of the desired elements. The exact composition of such electrolytes is not readily available in the open literature. One of the promising techniques in surface treatment of austenitic stainless steels is carburization. Traditionally, carburization was performed at high temperatures (up to $1000^{\circ} \mathrm{C}$ ) using a carbon source such as charcoal. Modern techniques, however, use carboncontaining gases or plasmas at a lower furnace temperature. Furnace temperature, reaction time and gas composition must be carefully selected and controlled to achieve desirable results. At high furnace temperatures, carburization leads to chromium depletion due to precipitation of the chromium carbide at grain boundaries, changing the microstructure of the material. High-temperature carburization often leads to higher hardness, but lower corrosion resistance. Accordingly, low-temperature carburization (between 450 $470^{\circ} \mathrm{C}$ ) is preferred to enhance the corrosion resistance of austenitic stainless steels while maintaining an acceptable hardness. Plasma carburization has been increasingly used to improve the surface properties of many metals, including stainless steels, owing to its environmentally friendly characteristics compared with solid or gaseous carburization. In addition, plasma carburization is more versatile since it can readily penetrate microgaps to give an even surface treatment; this is important in substrates with complex geometries.

Another promising surface treatment technique is the utilization of highly conductive and corrosion resistant coatings. As a result, a large number of coatings and processes have been developed to address the concerns associated with bare metallic bipolar plates and often are classified as carbon- and metal-based coatings. Carbon-based coatings include conductive polymers, graphite, diamond-like carbon, and organic self-assembled monopolymers, while prime examples of metal-based coatings are noble metals, metal carbides and metal nitrides. Extensive research on both of these coatings has been carried out and reported. It is generally agreed that such coatings must be conductive and adhere to the metallic bipolar plate substrate. Proper adhesion to the substrate is achieved by careful selection of coating materials having thermal expansion coefficients similar to those of the substrate to minimize micro- and macro-crack formation. There have been a large number of studies on the resilience of such coatings in both real and simulated fuel cell environments. However, there are several concerns with conductive layer coatings. First, there is always the possibility of imperfections such as pinholes and micro and macro cracks, which can lead to localized corrosion. This undermines the integrity of the plates and, most importantly, poisons the membrane when dissolved ions diffuse into the membrane and occupy the exchange sites, thereby lowering the ionic conductivity and the overall performance of the stack. Second, the cost and durability of such conductive layers has become an issue, since both are the main impediments to the commercialization of fuel cells. Several fuel cell manufacturers have developed both organic and inorganic protective and conductive coatings for metallic bipolar plates [46]. Although the use of inorganic protective coatings have been extensively studied, the utilization of organic coatings warrants further research. 


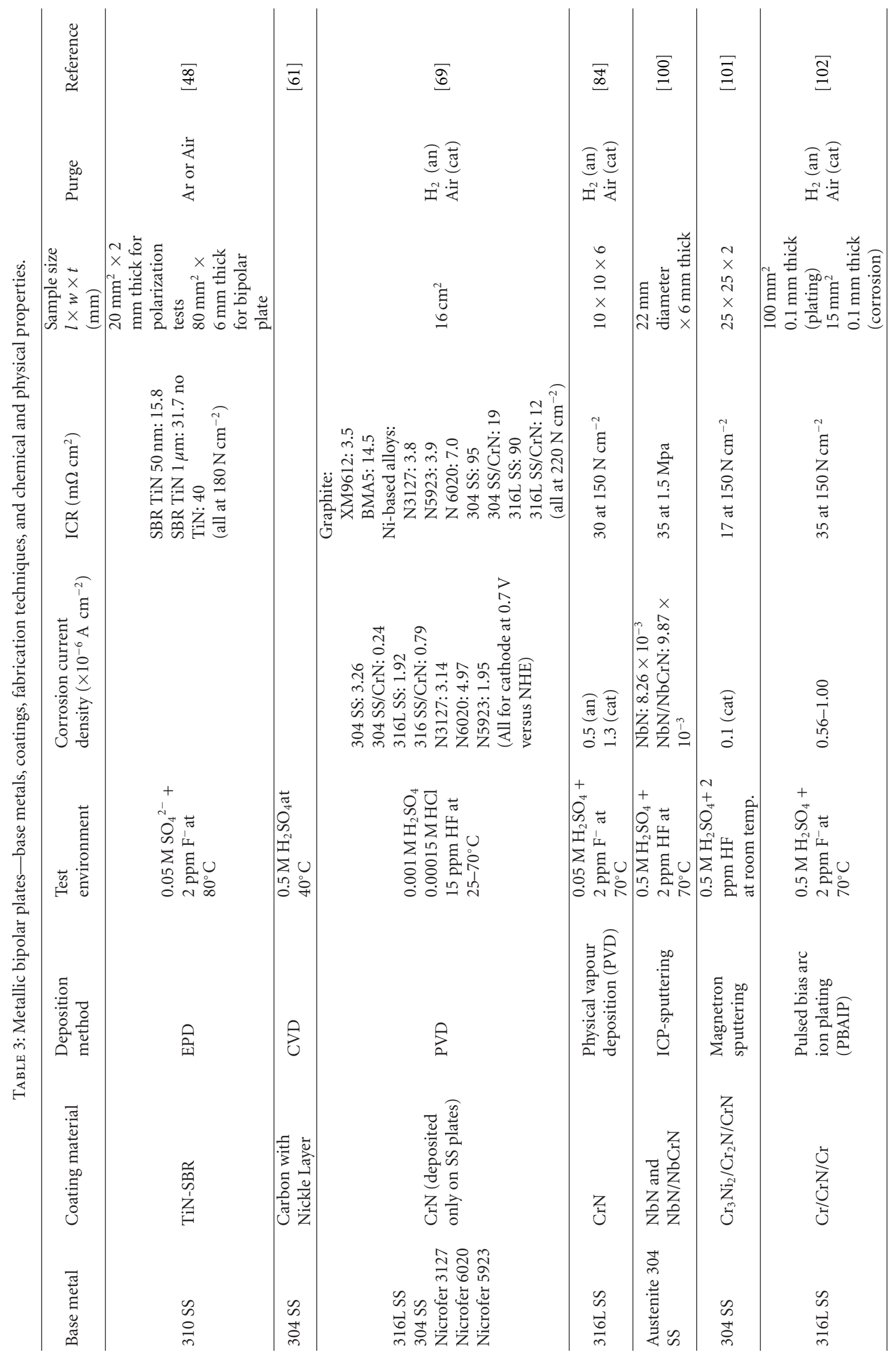


Advances in Materials Science and Engineering

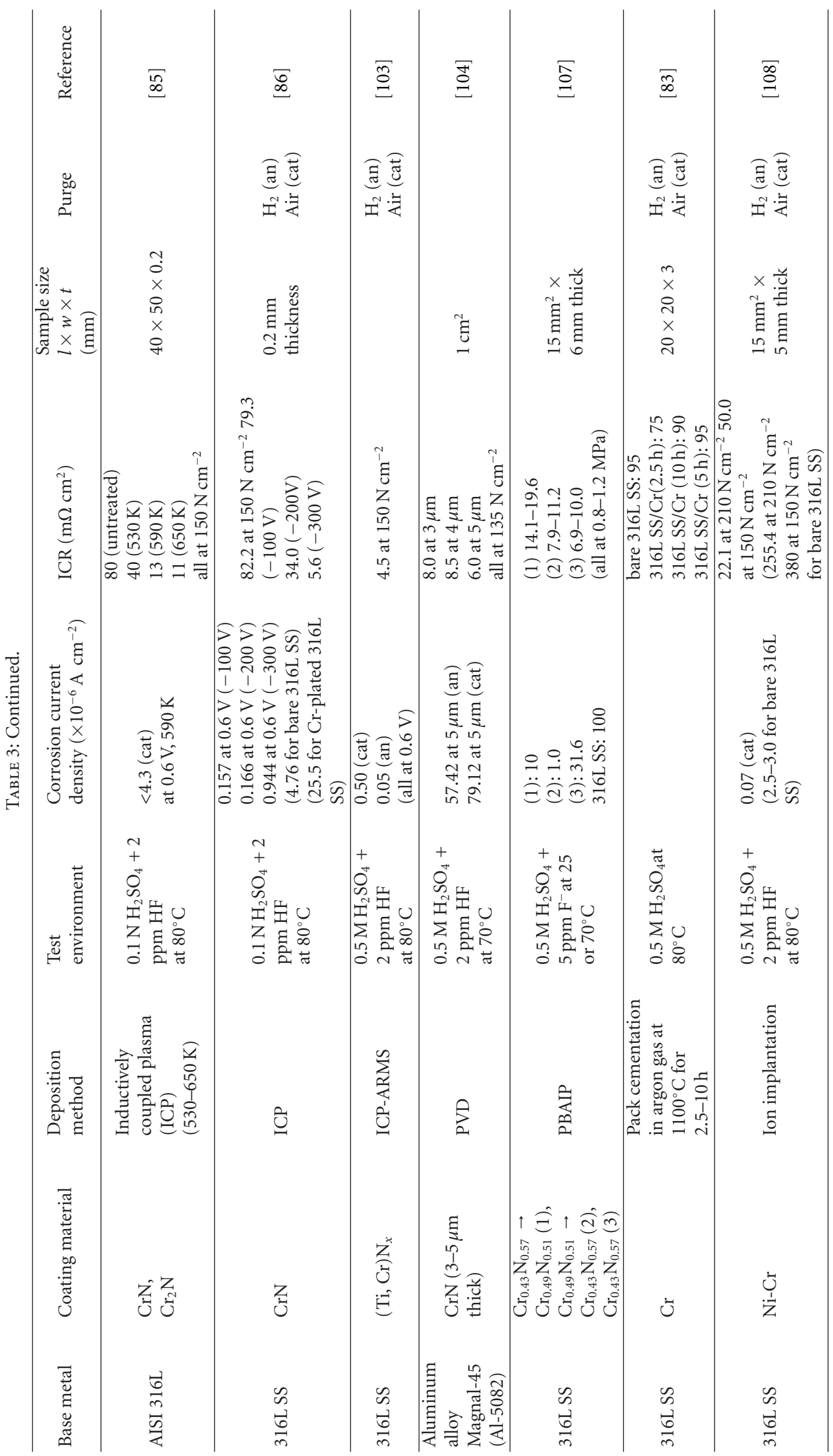




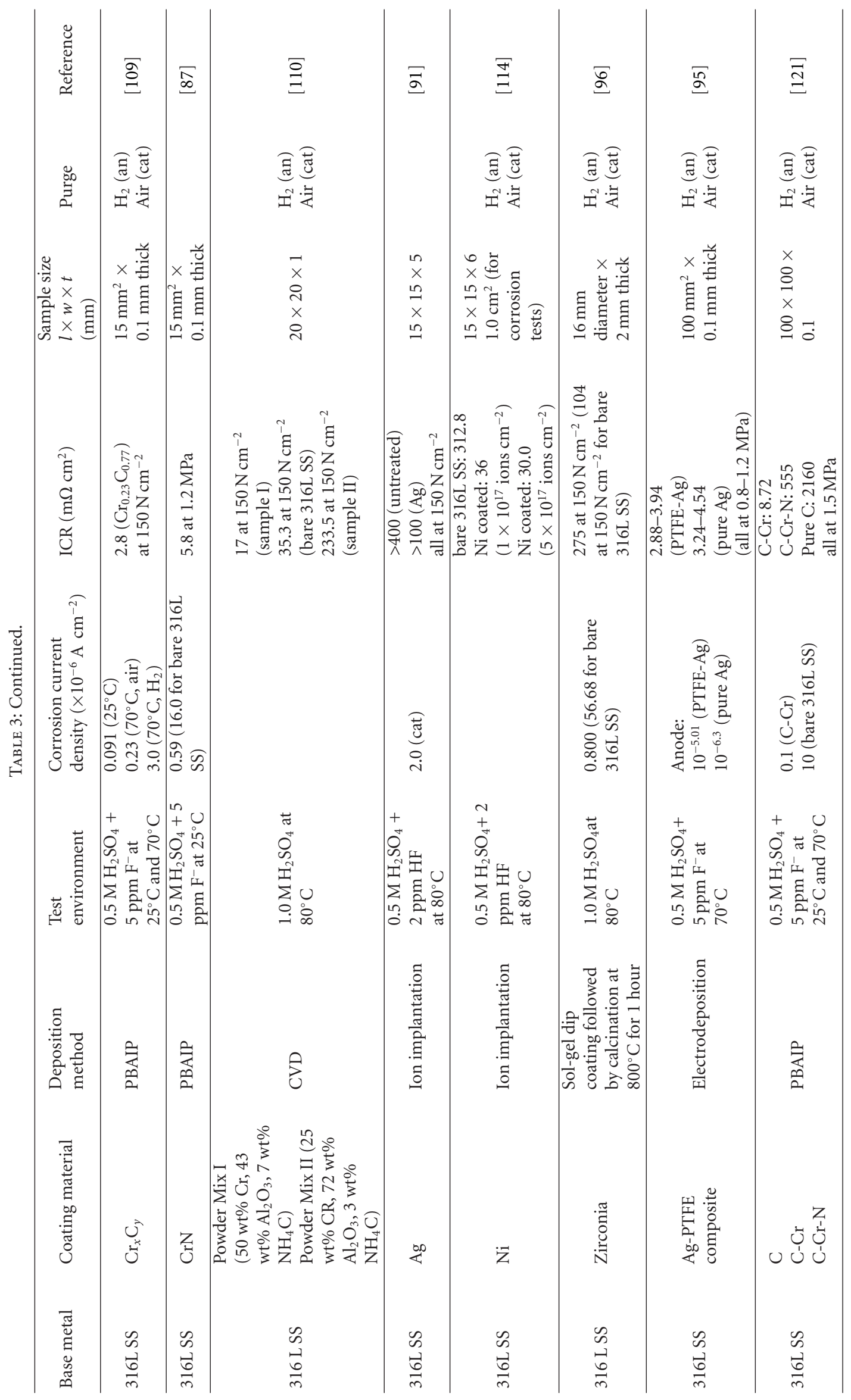




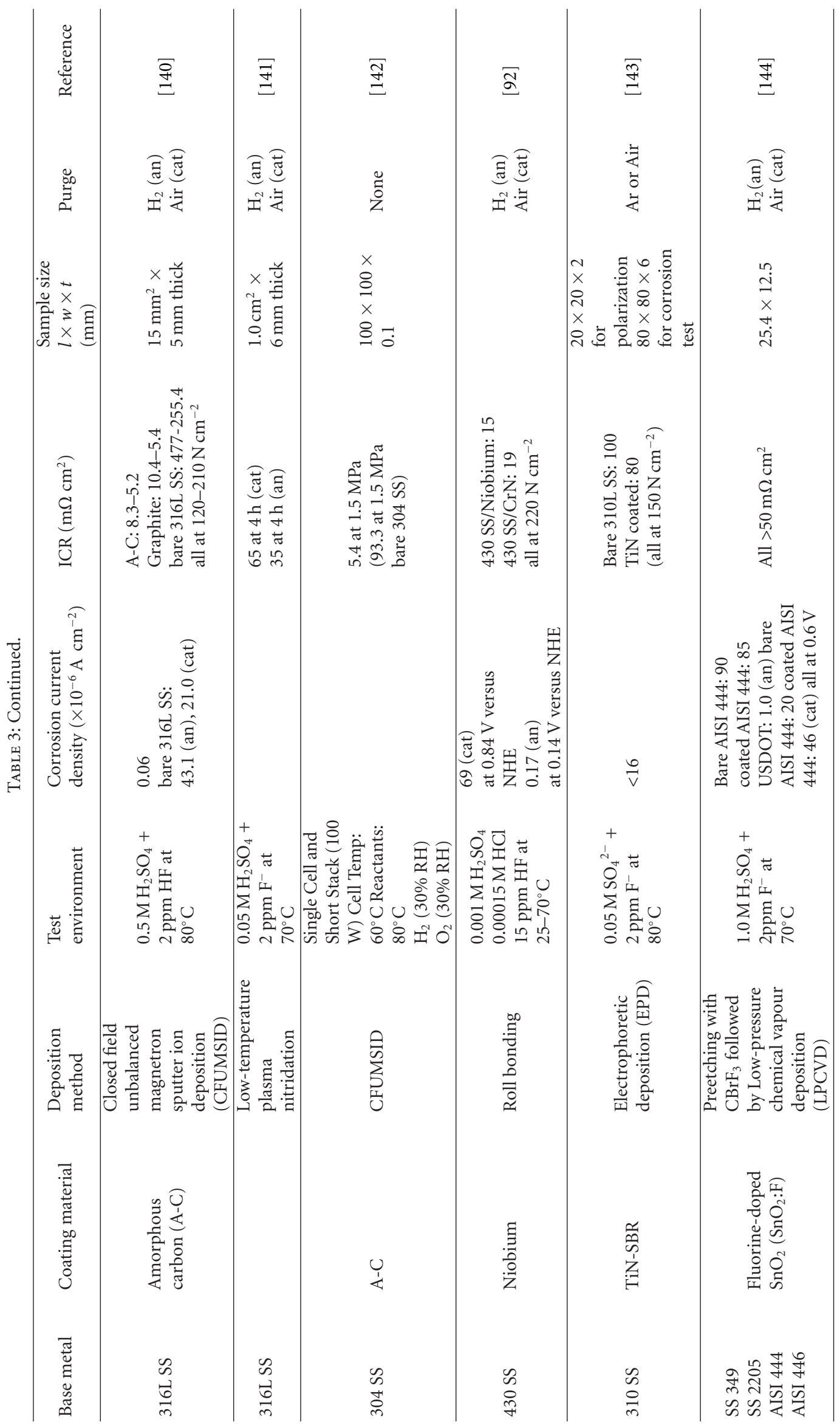


3.2.1. Metal and Nonmetal Nitride Films. There have been several publications featuring titanium nitride films on stainless steel plates, with favourable results; however, for mass production and cost curtailment, titanium should be avoided. Niobium nitride coatings have been investigated as well, but did not meet the DOE target for ICR. Chromium nitride is less expensive and has shown promising results; it is covered fully in the next section.

3.2.2. Chromium-Containing Films. $\mathrm{CrN}, \mathrm{NiCr}$, and $\mathrm{CrC}$ have all been investigated with varying success rates. Chromium nitride films have been applied to both aluminum and stainless steel bipolar plates, and it is generally agreed that a higher flow rate of nitrogen during CVD yields a more uniform layer with higher corrosion resistance and lower ICR in fuel cell environments. However, excess $\mathrm{Cr}$ can cause localized corrosion, poisoning the solid polymer electrolyte, leading to lower fuel cell performance. Nickel chromium coatings have been reported to lower the ICR; however, they are yet to meet the DOE target. Chromium carbide coatings with high chromium content have the best published results, with an ICR as low as $2.8 \mathrm{~m} \Omega \mathrm{cm}^{2}$ and a corrosion current of $9.1 \times 10^{-8} \mathrm{~A} \mathrm{~cm}^{-2}$ [109]. Future research should focus on determining the optimal $\mathrm{Cr}-\mathrm{C}$ ratio for such coatings.

3.2.3. Noble and Nonnoble Metal Coatings. Although great success has been made in lowering the ICR and corrosion rates by using various noble metals, including gold and platinum-group metals, the cost is too great for mass production in terrestrial applications. These types of plates are commonly used in high-performance fuel cells, where cost is less of a concern and performance is the primary factor; that is, space programs and military applications.

3.2.4. Composites, Conductive Polymers, and Carbon-Based Coatings. Composites, conductive polymers, and carbonbased coatings offer a wide variety of possibilities. With long term viability in mind, avoiding the use of expensive metals such as silver and gold will keep the cost down. Conductive polymer coatings offer excellent corrosion resistance and can offer unique fabrication processes such as injection molding, if the entire plate is made from the polymer. By lowering the ICR of such materials, polymer bipolar plates could become the new industry standard. Carbonbased chromium coatings are reported to exhibit many favourable characteristics and should be investigated further. The incorporation of conductive metal nanoparticles into such plates is another viable option that may prove useful in lowering ICR.

3.3. Fabrication of Metallic Bipolar Plates. The possibilities for fabrication of bipolar plates are very promising, as methods like stamping and hydroforming are already well established. How these processes will affect corrosion and interfacial contact resistance is, however, not well known. It has been shown that an increased stamping speed will produce a surface with a lower ICR, yet increasing the stamping force, will increase it. Further investigation into these fabrication methods is needed. The key to future fabrication of bipolar plates will be to design plates with the physical properties of metals in mind. The use of thin corrugated metal sheets, and avoiding expensive machining processes, will lower both cost and weight of future bipolar plates.

As the need for coatings on metallic bipolar plates becomes evident, many different processes are being investigated. Pack cementation of coatings onto bipolar plates is accomplished by applying a layer of the desired coating directly on the bipolar plate while heated in a furnace to high temperature. Although improvements have been observed in corrosion resistance, this process exhibits only marginal gains in ICR [83]. This can be attributed to the formation of columnar gaps and surface defects during extended pack cementation. Greater success has been achieved by using different closed space sublimation techniques, including electron beam evaporation, physical vapour deposition, and pulsed bias arc ion plating. Although more expensive, these methods show superior performance over long-term testing. Similar to physical vapour deposition, chemical vapour deposition also deposits a microfilm layer on the substrate.

In summary, metallic bipolar plates offer many advantages over traditional graphite, for example, ease of manufacturing and physical durability, however, susceptibility to corrosion and, to a lesser extent, high interfacial contact resistance have kept them from being the primary choice for the fabrication of fuel cells. In an attempt to combat this, research has been done on different corrosion resistant coatings, including, gold, silver, platinum, nickel, and several nitrides and carbides. Silver, gold, and platinum coatings are too expensive to consider for mass production, and nickel coatings do not meet the DOE requirement for ICR. Results for chromium nitride coatings have shown decreased corrosion as well, but also do not meet the DOE requirement for ICR. The most promising results have been obtained with chromium carbide coatings, with the stoichiometric ratio optimized in order to not leave excess chromium on the substrate. Different methods for depositing the corrosion resistant coatings have been researched in recent years as well, including CVD, PVD, EPD, pack cementation, ion implantation, sol-gel dip coating, and roll bonding. With cost as a major concern, most of these methods are not ideal for mass production. Future research should concentrate on a cost effective method for depositing a chromium carbide or amorphous carbon film on stainless steel plates.

\section{Conclusions}

Because of its high efficiency, low-temperature operation, high-power density, and relatively fast start up, the proton exchange membrane fuel cell offers the potential for a near-zero emission power source for transportation, mobile, and stationary applications. However, for such power sources to become mainstream and gain a sizable share of the market, they must be able to compete with other power sources in terms of cost, reliability, 
durability, and public acceptance. Cost and durability are two major factors that have impeded the introduction of fuel cells as primary energy sources into different sectors of the economy. Accordingly, identifying opportunities for cost reduction and cost avoidance in the selection and manufacture of the different components of PEMFCs, as well as improving their life expectancy, can significantly increase their chance of becoming a major player in the energy market. Bipolar plates play a vital role in PEMFCs in terms of operation and cost; consequently, lowering their cost and improving their performance are highly desirable. Such plates must be rigid, durable, conductive, stable in harsh environments and resist dimensional change at relatively high temperatures and under compressive loads.

A significant amount of work is currently focused on developing novel materials and fabrication processes to not only meet the above goals, but also to satisfy different market requirements. Bipolar plates have traditionally been fabricated from high-density graphite on account of its superior corrosion resistance, chemical stability, high thermal conductivity, and availability. However, due to its molecular structure, it exhibits poor mechanical properties, high manufacturing cost, and it is difficult to work with. As a result, recent studies have moved away from graphite in the direction of developing and optimizing more cost effective materials such as metals and composites. Nevertheless, graphite has established itself as the benchmark material for fabrication of bipolar plates, against which all other materials are compared. Metallic bipolar plates offer higher strength and electrical conductivity, better formability and manufacturability, lower gas permeability, and better shock resistance than graphite plates. Furthermore, their unique mechanical properties allow for fabrication of thinner plates and reduced scrap rates. They are, however, more susceptible to corrosion, which can adversely impact their performance and durability. This has necessitated the need for the application of corrosionresistant coatings to reduce or eliminate these effects. Most of the research in the past has focused on iron-based alloys, such as stainless steel, because of their low costs; however, more recently, considerable efforts have been expended to use noble metals, aluminum, and titanium as the material of choice for fabricating bipolar plates. Another advantage of metallic bipolar plates over graphitic bipolar plates is the availability and maturity of a large number of manufacturing processes that are cost effective, including stamping, compression-molding, and embossing. Composite plates offer improved mechanical properties and manufacturability over graphite plates, as well as a cost reduction; however, they are inferior in terms of electrical conductivity.

\section{Acknowledgment}

The financial support from the Natural Sciences and Engineering Research Council of Canada and Lambton College is gratefully acknowledged.

\section{References}

[1] S. H. Joo, H. I. Lee, D. J. You et al., "Ordered mesoporous carbons with controlled particle sizes as catalyst supports for direct methanol fuel cell cathodes," Carbon, vol. 46, no. 15, pp. 2034-2045, 2008.

[2] A. J. Appleby and F. R. Foulkes, Fuel Cell Handbook, Van Nostrand Reinhold, New York, NY, USA, 1989.

[3] Q. Dong, M. M. Mench, S. Cleghorn, and U. Beuscher, "Distributed performance of polymer electrolyte fuel cells under low-humidity conditions," Journal of the Electrochemical Society, vol. 152, no. 11, pp. A2114-A2122, 2005.

[4] K. H. Choi, H. S. Kim, and T. H. Lee, "Electrode fabrication for proton exchange membrane fuel cells by pulse electrodeposition," Journal of Power Sources, vol. 75, no. 2, pp. 230235, 1998.

[5] S. Kamarajugadda and S. Mazumder, "Numerical investigation of the effect of cathode catalyst layer structure and composition on polymer electrolyte membrane fuel cell performance," Journal of Power Sources, vol. 183, no. 2, pp. 629-642, 2008.

[6] S. M. Rao and Y. Xing, "Simulation of nanostructured electrodes for polymer electrolyte membrane fuel cells," Journal of Power Sources, vol. 185, no. 2, pp. 1094-1100, 2008.

[7] S. Woo, I. Kim, J. K. Lee, S. Bong, J. Lee, and H. Kim, "Preparation of cost-effective Pt-Co electrodes by pulse electrodeposition for PEMFC electrocatalysts," Electrochimica Acta, vol. 56, no. 8, pp. 3036-3041, 2011.

[8] X. Su, J. Wu, and B. J. Hinds, "Catalytic activity of ultrathin Pt films on aligned carbon nanotube arrays," Carbon, vol. 49, no. 4, pp. 1145-1150, 2011.

[9] E. Lebègue, S. Baranton, and C. Coutanceau, "Polyol synthesis of nanosized $\mathrm{Pt} / \mathrm{C}$ electrocatalysts assisted by pulse microwave activation," Journal of Power Sources, vol. 196, no. 3, pp. 920-927, 2011.

[10] C. J. Zhong, J. Luo, B. Fang et al., "Nanostructured catalysts in fuel cells," Nanotechnology, vol. 21, no. 3, Article ID 062001, 20 pages, 2010.

[11] A. Wolz, S. Zils, M. Michel, and C. Roth, "Structured multilayered electrodes of proton/electron conducting polymer for polymer electrolyte membrane fuel cells assembled by spray coating," Journal of Power Sources, vol. 195, no. 24, pp. 81628167, 2010.

[12] Y. Komoda, K. Okabayashi, H. Nishimura, M. Hiromitsu, T. Oboshi, and H. Usui, "Dependence of polymer electrolyte fuel cell performance on preparation conditions of slurry for catalyst layers," Journal of Power Sources, vol. 193, no. 2, pp. 488-494, 2009.

[13] A. Caillard, C. Charles, D. Ramdutt, R. Boswell, and P. Brault, "Effect of Nafion and platinum content in a catalyst layer processed in a radio frequency helicon plasma system," Journal of Physics D, vol. 42, no. 4, Article ID 045207, 9 pages, 2009.

[14] V. Ramani, S. Swier, M. T. Shaw, R. A. Weiss, H. R. Kunz, and J. M. Fenton, "Membranes and MEAs based on sulfonated poly(ether ketone ketone) and heteropolyacids for polymer electrolyte fuel cells," Journal of the Electrochemical Society, vol. 155, no. 6, pp. B532-B537, 2008.

[15] B. Lakshmanan, W. Huang, D. Olmeijer, and J. W. Weidner, "Polyetheretherketohe membranes for elevated temperature PEMFCs," Electrochemical and Solid-State Letters, vol. 6, no. 12, pp. A282-A285, 2003. 
[16] E. B. Easton, T. D. Astill, and S. Holdcroft, "Properties of gas diffusion electrodes containing sulfonated poly(ether ether ketone)," Journal of the Electrochemical Society, vol. 152, no. 4, pp. A752-A758, 2005.

[17] S. Chunhui, P. Mu, Y. Qin, and Y. Runzhang, "Studies on preparation and performance of sodium silicate/graphite conductive composites," Journal of Composite Materials, vol. 40, no. 9, pp. 839-848, 2006.

[18] H. Tsuchiya and O. Kobayashi, "Mass production cost of PEM fuel cell by learning curve," International Journal of Hydrogen Energy, vol. 29, no. 10, pp. 985-990, 2004.

[19] H. C. Kuan, C. C. M. Ma, K. H. Chen, and S. M. Chen, "Preparation, electrical, mechanical and thermal properties of composite bipolar plate for a fuel cell," Journal of Power Sources, vol. 134, no. 1, pp. 7-17, 2004.

[20] E. A. Cho, U.S. Jeon, and H. Y. Ha, "Characteristics of composite bipolar plates for polymer electrolyte membrane fuel cells," Journal of Power Sources, vol. 125, no. 2, pp. 178-182, 2004.

[21] A. Heinzel, F. Mahlendorf, O. Niemzig, and C. Kreuz, "Injection moulded low cost bipolar plates for PEM fuel cells," Journal of Power Sources, vol. 131, no. 1-2, pp. 35-40, 2004.

[22] C. Shen, M. Pan, Z. Hua, and R. Yuan, "Aluminate cement/ graphite conductive composite bipolar plate for proton exchange membrane fuel cells," Journal of Power Sources, vol. 166, no. 2, pp. 419-423, 2007.

[23] B. D. Cunningham, J. Huang, and D. G. Baird, "Development of bipolar plates for fuel cells from graphite filled wet-lay material and a thermoplastic laminate skin layer," Journal of Power Sources, vol. 165, no. 2, pp. 764-773, 2007.

[24] B. Cunningham and D. G. Baird, "The development of economical bipolar plates for fuel cells," Journal of Materials Chemistry, vol. 16, no. 45, pp. 4385-4388, 2006.

[25] Y. Wang and D. O. Northwood, "Effects of $\mathrm{O}_{2}$ and $\mathrm{H}_{2}$ on the corrosion of SS316 metallic bipolar plate materials in simulated anode and cathode environments of PEM fuel cells," Electrochimica Acta, vol. 52, no. 24, pp. 6793-6798, 2007.

[26] X. Li and I. Sabir, "Review of bipolar plates in PEM fuel cells: flow-field designs," International Journal of Hydrogen Energy, vol. 30, no. 4, pp. 359-371, 2005.

[27] C. Shen, M. Pan, Z. Hua, and R. Yuan, "Aluminate cement/ graphite conductive composite bipolar plate for proton exchange membrane fuel cells," Journal of Power Sources, vol. 166, no. 2, pp. 419-423, 2007.

[28] E. A. Cho, U. S. Jeon, H. Y. Ha, S. A. Hong, and I. H. Oh, "Characteristics of composite bipolar plates for polymer electrolyte membrane fuel cells," Journal of Power Sources, vol. 125, no. 2, pp. 178-182, 2004.

[29] S. Chunhi, P. Mu, H. Zhoufa, and Y. Runzhang, "Performance of an aluminate cement /graphite conductive composite bipolar plate," Journal of Power Sources, vol. 159, no. 2, pp. 1078-1083, 2006.

[30] A. Hermann, T. Chaudhuri, and P. Spagnol, "Bipolar plates for PEM fuel cells: a review," International Journal of Hydrogen Energy, vol. 30, no. 12, pp. 1297-1302, 2005.

[31] Z. Bin, M. Bingchu, S. Chunhui, and Y. Runzhang, "Study on the electrical and mechanical properties of polyvinylidene fluroide/titanium silicon carbide composite bipolar plates," Journal of Power Sources, vol. 161, no. 2, pp. 997-1001, 2006.

[32] R. G. Sheppard, D. M. Mathes, and D. J. Bray, "Properties and Characteristics of Graphite for Industrial Applications," Poco Graphite, pp. 5-7, 2001.
[33] R. L. Borup and N. E. Vanderborgh, "Design and testing criteria for bipolar plate material for PEM fuel cell application," Materials Research Society Symposium Proceedings, vol. 393, pp. 151-155, 1995.

[34] V. Mehta and J. S. Cooper, "Review and analysis of PEM fuel cell design and manufacturing," Journal of Power Sources, vol. 114, no. 1, pp. 32-53, 2003.

[35] J. S. Cooper, "Design analysis of PEMFC bipolar plates considering stack manufacturing and environment impact," Journal of Power Sources, vol. 129, no. 2, pp. 152-169, 2004.

[36] X. Z. Yuan, H. Wang, J. Zhang, and D. P. Wilkinson, "Bipolar plates for PEM fuel cells-from materials to processing," Journal of New Materials for Electrochemical Systems, vol. 8, no. 4, pp. 257-267, 2005.

[37] D. J. L. Brett and N. P. Brandon, "Review of materials and characterization methods for polymer electrolyte fuel cell flow-field plates," Journal of Fuel Cell Science and Technology, vol. 4, no. 1, pp. 29-44, 2007.

[38] H. Tawfik, Y. Hung, and D. Mahajan, "Metal bipolar plates for PEM fuel cell-A review," Journal of Power Sources, vol. 163, no. 2, pp. 755-767, 2007.

[39] M. Li, L. Zhang, S. Wang, and S. J. Hu, "Design, manufacturing, and performance of PEM fuel cell metallic bipolar plates," Journal of Fuel Cell Science and Technology, vol. 5, no. $1,2008$.

[40] H. Wang and J. A. Turner, "Reviewing metallic PEMFC bipolar plates," Fuel Cells, vol. 10, no. 4, pp. 510-519, 2010.

[41] P. J. Hamilton and B. G. Pollet, "Polymer electrolyte membrane fuel cell (PEMFC) flow field plate: design, materials and characterisation," Fuel Cells, vol. 10, no. 4, pp. 489-509, 2010.

[42] D. N. Busick and M. S. Wilson, "Low-cost composite materials for PEFC bipolar plates," Fuel Cells Bulletin, vol. 2, no. 5, pp. 6-8, 1999.

[43] T. Cheng, "Bipolar plates and plate materials," in Proton Exchange Membrane Fuel Cells: Materials Properties and Performance, D. P. Wilkinson, J. Zhang, R. Hui, J. Fergus, and X. Li, Eds., pp. 307-326, Taylor \& Francis Group, Boca Raton, Fla, USA, 2010.

[44] B. Cunningham, The development of compression moldable polymer composite bipolar plates for fuel cells [Ph.D. dissertation], Virginia Polytechnic Institute and State University, 2007.

[45] K. RoBerg and V. Trapp, "Graphite-based bipolar plates," in Handbook of Fuel Cells Fundamentals, Technology and Applications, W. Vielstich, A. Lamm, and H. A. Gasteiger, Eds., pp. 308-314, John Wiley \& Sons, 2003.

[46] Y. Hung, H. Tawfik, and D. Mahajan, "Durability and characterization studies of polymer electrolyte membrane fuel cell's coated aluminum bipolar plates and membrane electrode assembly," Journal of Power Sources, vol. 186, no. 1, pp. 123127, 2009.

[47] J. André, L. Antoni, and J. P. Petit, "Corrosion resistance of stainless steel bipolar plates in a PEFC environment: a comprehensive study," International Journal of Hydrogen Energy, vol. 35, no. 8, pp. 3684-3697, 2010.

[48] M. Kumagai, S. T. Myung, S. Kuwata, R. Asaishi, and H. Yashiro, "Corrosion behavior of austenitic stainless steels as a function of $\mathrm{pH}$ for use as bipolar plates in polymer electrolyte membrane fuel cells," Electrochimica Acta, vol. 53, no. 12, pp. 4205-4212, 2008.

[49] H. Wang, M. A. Sweikart, and J. A. Turner, "Stainless steel as bipolar plate material for polymer electrolyte membrane fuel 
cells," Journal of Power Sources, vol. 115, no. 2, pp. 243-251, 2003.

[50] R. Hornung and G. Keppelt, "Bipolar plate materials development using Fe-based alloys for solid polymer fuel cells," Journal of Power Sources, vol. 72, no. 1, pp. 20-21, 1998.

[51] R. C. Makkus, A. H. H. Janssen, F. A. De Bruijn, and R. K. A. M. Mallant, "Use of stainless steel for cost competitive bipolar plates in the SPFC," Journal of Power Sources, vol. 86, no. 1, pp. 274-282, 2000.

[52] P. L. Hentall, J. Barry Lakeman, G. O. Mepsted, P. L. Adcock, and J. M. Moore, "New materials for polymer electrolyte membrane fuel cell current collectors," Journal of Power Sources, vol. 80, no. 1, pp. 235-241, 1999.

[53] D. P. Davies, P. L. Adcock, M. Turpin, and S. J. Rowen, "Bipolar plate materials for solid polymer fuel cells," Journal of Applied Electrochemistry, vol. 30, no. 1, pp. 101-105, 2000.

[54] D. P. Davies, P. L. Adcock, M. Turpin, and S. J. Rowen, "Stainless steel as a bipolar plate material for solid polymer fuel cells," Journal of Power Sources, vol. 86, no. 1, pp. 237242, 2000.

[55] "Properties of radiation grafted membranes for fuel cell applications," in Proceedings of the Second International Symposium, J. Scholta, B. Rohland, J. Garche, and P. R. Roberge, Eds., p. 300, Ecole Polytechnique de Montreal, Quebec, Canada, 1997.

[56] L. Ma, S. Warthesen, and D. A. Shores, "Evaluation of materials for bipolar plates in PEMFCs," Journal of New Materials for Electrochemical Systems, vol. 3, no. 3, pp. 221-228, 2000.

[57] S. Joseph, J. C. McClure, R. Chianelli, P. Pich, and P. J. Sebastian, "Conducting polymer-coated stainless steel bipolar plates for proton exchange membrane fuel cells (PEMFC)," International Journal of Hydrogen Energy, vol. 30, no. 12, pp. 1339-1344, 2005.

[58] M. A. L. García and M. A. Smit, "Study of electrodeposited polypyrrole coatings for the corrosion protection of stainless steel bipolar plates for the PEM fuel cell," Journal of Power Sources, vol. 158, no. 1, pp. 397-402, 2006.

[59] R. Tian, J. Sun, and L. Wang, "Plasma-nitrided austenitic stainless steel 316L as bipolar plate for PEMFC," International Journal of Hydrogen Energy, vol. 31, no. 13, pp. 1874-1878, 2006.

[60] Y. Wang and D. O. Northwood, "An investigation into TiNcoated 316L stainless steel as a bipolar plate material for PEM fuel cells," Journal of Power Sources, vol. 165, no. 1, pp. 293 298, 2007.

[61] C. Y. Chung, S. K. Chen, P. J. Chiu, M. H. Chang, T. T. Hung, and T. H. Ko, "Carbon film-coated 304 stainless steel as PEMFC bipolar plate," Journal of Power Sources, vol. 176, no. 1, pp. 276-281, 2008.

[62] T. Fukutsuka, T. Yamaguchi, S. I. Miyano, Y. Matsuo, Y. Sugie, and Z. Ogumi, "Carbon-coated stainless steel as PEFC bipolar plate material," Journal of Power Sources, vol. 174, no. 1, pp. 199-205, 2007.

[63] V. V. Nikam and R. G. Reddy, "Corrosion studies of a copperberyllium alloy in a simulated polymer electrolyte membrane fuel cell environment," Journal of Power Sources, vol. 152, no. 1-2, pp. 146-155, 2005.

[64] G. Moretti and F. Guidi, "Tryptophan as copper corrosion inhibitor in $0.5 \mathrm{M}$ aerated sulfuric acid," Corrosion Science, vol. 44, no. 9, pp. 1995-2011, 2002.

[65] L. Shreir, Corrosion in Aqueous Solution, Corrosion, Butterworth-Heinemann, Oxford, UK, 3rd edition, 1994.
[66] V. V. Nikam, Copper alloy bipolar/end plates in polymer electrolyte membrane fuel cells [M.S. thesis], The University of Alabama, Tuscaloosa, Ala, USA, 2004.

[67] A. M. Lafront, E. Ghali, and A. T. Morales, "Corrosion behavior of two bipolar plate materials in simulated PEMFC environment by electrochemical noise technique," Electrochimica Acta, vol. 52, no. 15, pp. 5076-5085, 2007.

[68] V. V. Nikam, R. G. Reddy, S. R. Collins, P. C. Williams, G. H. Schiroky, and G. W. Henrich, "Corrosion resistant low temperature carburized SS 316 as bipolar plate material for PEMFC application," Electrochimica Acta, vol. 53, no. 6, pp. 2743-2750, 2008.

[69] A. Pozio, F. Zaza, A. Masci, and R. F. Silva, "Bipolar plate materials for PEMFCs: a conductivity and stability study," Journal of Power Sources, vol. 179, no. 2, pp. 631-639, 2008.

[70] Y. Yang, L. J. Guo, and H. Liu, "Corrosion characteristics of SS316L as bipolar plate material in PEMFC cathode environments with different acidities," International Journal of Hydrogen Energy, vol. 36, no. 2, pp. 1654-1663, 2011.

[71] H. Wang and J. A. Turner, "Ferritic stainless steels as bipolar plate material for polymer electrolyte membrane fuel cells," Journal of Power Sources, vol. 128, no. 2, pp. 193-200, 2004.

[72] M. Kumagai, S. T. Myung, T. Ichikawa, and H. Yashiro, "Applicability of extra low interstitials ferritic stainless steels for bipolar plates of proton exchange membrane fuel cells," Journal of Power Sources, vol. 195, no. 21, pp. 7181-7186, 2010.

[73] A. V. Nikiforov, I. M. Petrushina, E. Christensen, A. L. Tomás-García, and N. J. Bjerrum, "Corrosion behaviour of construction materials for high temperature steam electrolysers," International Journal of Hydrogen Energy, vol. 36, no. 1, pp. 111-119, 2011.

[74] Y. I. Bil'chugov, N. L. Makarova, and A. A. Nazarov, "On limit of molybdenum content of pitting-corrosion-resistant austenitic steels," Protection of Metals, vol. 37, no. 6, pp. 597$601,2001$.

[75] A. Asphahani and S. J. Matthews, US Patent No. 4846885, 1989.

[76] R. Tian and J. Sun, "Performance of a high Cr and Ni austenitic stainless steel bipolar plates in proton exchange membrane fuel cell working environments," Journal of Power Sources, vol. 194, no. 2, pp. 981-984, 2009.

[77] H. Wang and J. A. Turner, "Austenitic stainless steels in high temperature phosphoric acid," Journal of Power Sources, vol. 180, no. 2, pp. 803-807, 2008.

[78] H. Wang and J. A. Turner, "Anodic behavior of high nitrogenbearing steels in PEMFC environments," Journal of Power Sources, vol. 180, no. 2, pp. 791-796, 2008.

[79] M. Kumagai, S. T. Myung, R. Asaishi, Y. Katada, and H. Yashiro, "High nitrogen stainless steel as bipolar plates for proton exchange membrane fuel cells," Journal of Power Sources, vol. 185, no. 2, pp. 815-821, 2008.

[80] Y. Hung, K. M. El-Khatib, and H. Tawfik, "Testing and evaluation of aluminum coated bipolar plates of pem fuel cells operating at $70^{\circ} \mathrm{C}$," Journal of Power Sources, vol. 163, no. 1, pp. 509-513, 2006.

[81] A. Woodham, E. Anderson, K. Jayne, and M. Kimble, "Development of corrosion-resistant coatings for fuel cell bipolar plates," in Proceedings of the American Electroplaters and Surface Finishers Society (AESF SUR/Fin '99), vol. 6, 1999.

[82] J. Wind, R. Spah, W. Kaiser, and G. Bohm, "Metallic bipolar plates for PEM fuel cells," Journal of Power Sources, vol. 105, no. 2, pp. 256-260, 2002. 
[83] K. H. Cho, W. G. Lee, S. B. Lee, and H. Jang, "Corrosion resistance of chromized $316 \mathrm{~L}$ stainless steel for PEMFC bipolar plates," Journal of Power Sources, vol. 178, no. 2, pp. 671-676, 2008.

[84] R. Tian, "Chromium nitride/Cr coated 316L stainless steel as bipolar plate for proton exchange membrane fuel cell," Journal of Power Sources, vol. 196, no. 3, pp. 1258-1263, 2011.

[85] W. Hong, D. H. Han, H. Choi, M. W. Kim, and J. J. Lee, "High-density plasma nitriding of AISI 316L for bipolar plate in proton exchange membrane fuel cell," International Journal of Hydrogen Energy, vol. 36, no. 3, pp. 2207-2212, 2011.

[86] D. H. Han, W. H. Hong, H. S. Choi, and J. J. Lee, "Inductively coupled plasma nitriding of chromium electroplated AISI 316L stainless steel for PEMFC bipolar plate," International Journal of Hydrogen Energy, vol. 34, no. 5, pp. 2387-2395, 2009.

[87] B. Wu, Y. Fu, J. Xu, G. Lin, and M. Hou, "Chromium nitride films on stainless steel as bipolar plate for proton exchange membrane fuel cell," Journal of Power Sources, vol. 194, no. 2, pp. 976-980, 2009.

[88] Y. H. Yun, "Deposition of gold-titanium and gold-nickel coatings on electropolished 316L stainless steel bipolar plates for proton exchange membrane fuel cells," International Journal of Hydrogen Energy, vol. 35, no. 4, pp. 1713-1718, 2010.

[89] I. Zafar, J. Guiheen, N. Dave, and R. Timothy, World Patent WO00, 128, 019, 2001.

[90] T. Matsumoto, J. Niikura, H. Ohara et al., European Patent EP, 1094535, 2001.

[91] K. Feng, Z. Li, X. Cai, and P. Chu, "Silver implanted 316L stainless steel as bipolar plates in polymer electrolyte membrane fuel cells," Materials Chemistry and Physics, vol. 126, no. 1-2, pp. 6-11, 2011.

[92] A. Pozio, R. F. Silva, and A. Masci, "Corrosion study of SS430/Nb as bipolar plate materials for PEMFCs," International Journal of Hydrogen Energy, vol. 33, no. 20, pp. 56975702, 2008.

[93] S. H. Wang, J. Peng, W. B. Lui, and J. S. Zhang, "Performance of the gold-plated titanium bipolar plates for the light weight PEM fuel cells," Journal of Power Sources, vol. 162, no. 1, pp. 486-491, 2006.

[94] S. H. Wang, J. Peng, and W. B. Lui, "Surface modification and development of titanium bipolar plates for PEM fuel cells," Journal of Power Sources, vol. 160, no. 1, pp. 485-489, 2006.

[95] Y. Fu, M. Hou, H. Xu et al., "Ag-polytetrafluoroethylene composite coating on stainless steel as bipolar plate of proton exchange membrane fuel cell," Journal of Power Sources, vol. 182, no. 2, pp. 580-584, 2008.

[96] W. G. Lee, K. H. Cho, S. B. Lee, S. B. Park, and H. Jang, "Electrochemical response of zirconia-coated 316L stainlesssteel in a simulated proton exchange membrane fuel cell environment," Journal of Alloys and Compounds, vol. 474, no. 1-2, pp. 268-272, 2009.

[97] M. Li, S. Lou, C. Zeng, J. Shen, H. Lin, and C. Cao, "Corrosion behavior of TiN coated type 316 stainless steel in simulated PEMFC environments," Corrosion Science, vol. 46, no. 6, pp. 1369-1380, 2004.

[98] L. Wang, D. O. Northwood, X. Nie et al., "Corrosion properties and contact resistance of TiN, TiAlN and CrN coatings in simulated proton exchange membrane fuel cell environments," Journal of Power Sources, vol. 195, no. 12, pp. 3814-3821, 2010.
[99] A. Taniguchi and K. Yasuda, "Highly water-proof coating of gas flow channels by plasma polymerization for PEM fuel cells," Journal of Power Sources, vol. 141, no. 1, pp. 8-12, 2005.

[100] B. C. Cha, Y. Z. You, S. T. Hong et al., "Nitride films as protective layers for metallic bipolar plates of polymer electrolyte membrane fuel cell stacks," International Journal of Hydrogen Energy, vol. 36, no. 7, pp. 4565-4572, 2011.

[101] D. Zhang, L. Guo, L. Duan, and W. H. Tuan, "Preparation of Cr-based multilayer coating on stainless steel as bipolar plate for PEMFCs by magnetron sputtering," International Journal of Hydrogen Energy, vol. 36, no. 3, pp. 2184-2189, 2011.

[102] M. Zhang, B. Wu, G. Lin, Z. Shao, M. Hou, and B. Yi, "Arc ion plated $\mathrm{Cr} / \mathrm{CrN} / \mathrm{Cr}$ multilayers on $316 \mathrm{~L}$ stainless steel as bipolar plates for polymer electrolyte membrane fuel cells," Journal of Power Sources, vol. 196, no. 6, pp. 3249-3254, 2011.

[103] H. S. Choi, D. H. Han, W. H. Hong, and J. J. Lee, "(Titanium, chromium) nitride coatings for bipolar plate of polymer electrolyte membrane fuel cell," Journal of Power Sources, vol. 189, no. 2, pp. 966-971, 2009.

[104] J. Barranco, F. Barreras, A. Lozano, and M. Maza, "Influence of CrN-coating thickness on the corrosion resistance behaviour of aluminium-based bipolar plates," Journal of Power Sources, vol. 196, no. 9, pp. 4283-4289, 2011.

[105] M. P. Brady, K. Weisbrod, I. Paulauskas et al., "Preferential thermal nitridation to form pin-hole free $\mathrm{Cr}$-nitrides to protect proton exchange membrane fuel cell metallic bipolar plates," Scripta Materialia, vol. 50, no. 7, pp. 1017-1022, 2004.

[106] S. H. Lee, J. H. Kim, Y. Y. Lee, and D. M. Wee, "Effects of low-temperature nitridation on the electrical conductivity and corrosion resistance of $446 \mathrm{M}$ stainless steel as bipolar plates for proton exchange membrane fuel cell," International Journal of Hydrogen Energy, vol. 35, no. 2, pp. 725-730, 2010.

[107] Y. Fu, M. Hou, G. Lin, J. Hou, Z. Shao, and B. Yi, "Coated $316 \mathrm{~L}$ stainless steel with $\mathrm{Cr}_{x} \mathrm{~N}$ film as bipolar plate for PEMFC prepared by pulsed bias arc ion plating," Journal of Power Sources, vol. 176, no. 1, pp. 282-286, 2008.

[108] K. Feng, Y. Shen, D. Liu, P. K. Chu, and X. Cai, "Ni-Cr Coimplanted 316L stainless steel as bipolar plate in polymer electrolyte membrane fuel cells," International Journal of Hydrogen Energy, vol. 35, no. 2, pp. 690-700, 2010.

[109] B. Wu, G. Lin, Y. Fu, M. Hou, and B. Yi, "Chromiumcontaining carbon film on stainless steel as bipolar plates for proton exchange membrane fuel cells," International Journal of Hydrogen Energy, vol. 35, no. 24, pp. 13255-13261, 2010.

[110] S. B. Lee, K. H. Cho, W. G. Lee, and H. Jang, "Improved corrosion resistance and interfacial contact resistance of 316L stainless-steel for proton exchange membrane fuel cell bipolar plates by chromizing surface treatment," Journal of Power Sources, vol. 187, no. 2, pp. 318-323, 2009.

[111] S. S. Dihrab, K. Sopian, M. A. Alghoul, and M. Y. Sulaiman, "Review of the membrane and bipolar plates materials for conventional and unitized regenerative fuel cells," Renewable and Sustainable Energy Reviews, vol. 13, no. 6-7, pp. 16631668, 2009.

[112] H. Y. Jung, S. Y. Huang, and B. N. Popov, "High-durability titanium bipolar plate modified by electrochemical deposition of platinum for unitized regenerative fuel cell (URFC)," Journal of Power Sources, vol. 195, no. 7, pp. 1950-1956, 2010.

[113] W. Yoon, X. Huang, P. Fazzino, K. L. Reifsnider, and M. A. Akkaoui, "Evaluation of coated metallic bipolar plates for polymer electrolyte membrane fuel cells," Journal of Power Sources, vol. 179, no. 1, pp. 265-273, 2008. 
[114] K. Feng, Y. Shen, J. Mai, D. Liu, and X. Cai, "An investigation into nickel implanted 316L stainless steel as a bipolar plate for PEM fuel cell," Journal of Power Sources, vol. 182, no. 1, pp. 145-152, 2008.

[115] P. Mondal, A. Klein, W. Jaegermann, and H. Hahn, "Enhanced specific grain boundary conductivity in nanocrystalline $\mathrm{Y}_{2} \mathrm{O}_{3}$-stabilized zirconia," Solid State Ionics, vol. 118, no. 3-4, pp. 331-339, 1999.

[116] J. Kimpton, T. H. Randle, and J. Drennan, "Investigation of electrical conductivity as a function of dopant-ion radius in the systems $\mathrm{Zr}_{0.75} \mathrm{Ce}_{0.08} \mathrm{M}_{0.17} \mathrm{O}_{1.92}(\mathrm{M}=\mathrm{Nd}, \mathrm{Sm}, \mathrm{Gd}$, Dy, Ho, Y, Er, Yb, Sc)," Solid State Ionics, vol. 149, no. 1-2, pp. 89-98, 2002.

[117] M. Hirano, S. Watanabe, E. Kato, Y. Mizutani, M. Kawai, and Y. Nakamura, "High electrical conductivity and high fracture strength of $\mathrm{Sc}_{2} \mathrm{O}_{3}$-doped zirconia ceramics with submicrometer grains," Journal of the American Ceramic Society, vol. 82, no. 10, pp. 2861-2864, 1999.

[118] J. K. Kuo and C. K. Chen, "A novel Nylon-6-S316L fiber compound material for injection molded PEM fuel cell bipolar plates," Journal of Power Sources, vol. 162, no. 1, pp. 207-214, 2006.

[119] Y. Wang and D. O. Northwood, "An investigation into polypyrrole-coated 316L stainless steel as a bipolar plate material for PEM fuel cells," Journal of Power Sources, vol. 163, no. 1, pp. 500-508, 2006.

[120] S. J. Lee, C. H. Huang, J. J. Lai, and Y. P. Chen, "Corrosionresistant component for PEM fuel cells," Journal of Power Sources, vol. 131, no. 1-2, pp. 162-168, 2004.

[121] Y. Fu, G. Lin, M. Hou, B. Wu, Z. Shao, and B. Yi, "Carbonbased films coated 316L stainless steel as bipolar plate for proton exchange membrane fuel cells," International Journal of Hydrogen Energy, vol. 34, no. 1, pp. 405-409, 2009.

[122] M. P. Brady, J. h. Schneibch, B. A. Pint, and P. J. Maziasz, US Patent No. 7, 211, 2007.

[123] M. P. Brady, H. Wang, and J. A. Turner, US Patent No. 7, 247, 403, 2007.

[124] M. K. Badinski, US Patent No. 7, 396, 559, 2008.

[125] M. H. Fronk, R. L. Borup, J. S. Hulett, B. K. Brady, and K. M. Cunnigham, US Patent No. 6, 372, 376, 2002.

[126] J. Yoshimura, Y. Nonobe, and K. Yamane, US Patent No. 6, 291, 094, 2001.

[127] H. Tawfik and Y. Hung, US Patent No. 7, 144, 648, 2006.

[128] F. Dundar, E. Dur, S. Mahabunphachai, and M. Koc, "Corrosion resistance characteristics of stamped and hydroformed proton exchange membrane fuel cell metallic bipolar plates," Journal of Power Sources, vol. 195, no. 11, pp. 3546-3552, 2010.

[129] L. Peng, X. Lai, D. Liu, P. Hu, and J. Ni, "Flow channel shape optimum design for hydroformed metal bipolar plate in PEM fuel cell," Journal of Power Sources, vol. 178, no. 1, pp. 223230, 2008.

[130] Y. Liu and L. Hua, "Fabrication of metallic bipolar plate for proton exchange membrane fuel cells by rubber pad forming," Journal of Power Sources, vol. 195, no. 11, pp. 35293535, 2010.

[131] H. N. Yu, S. S. Kim, J. D. Suh, and D. G. Lee, "Composite endplates with pre-curvature for PEMFC (polymer electrolyte membrane fuel cell)," Composite Structures, vol. 92, no. 6, pp. 1498-1503, 2010.

[132] H. N. Yu, S. S. Kim, J. D. Suh, and D. G. Lee, "Axiomatic design of the sandwich composite endplate for PEMFC in fuel cell vehicles," Composite Structures, vol. 92, no. 6, pp. 1504-1511, 2010.
[133] V. V. Nikam and R. G. Reddy, "Corrugated bipolar sheets as fuel distributors in PEMFC," International Journal of Hydrogen Energy, vol. 31, no. 13, pp. 1863-1873, 2006.

[134] P. Y. Yi, L. F. Peng, X. M. Lai, D. A. Liu, and J. Ni, "A novel design of wave-like PEMFC stack with undulate MEAs and perforated bipolar plates," Fuel Cells, vol. 10, no. 1, pp. 111$117,2010$.

[135] M. S. Chandrasekar and M. Pushpavanam, "Pulse and pulse reverse plating-conceptual, advantages and applications," Electrochimica Acta, vol. 53, no. 8, pp. 3313-3322, 2008.

[136] M. C. Kimble, A. S. Woodman, and E. B. Anderson, "Microfuel cells and electrolyzers for UAVs," in Proceedings of the American Electroplaters and Surface Finishers Society (AESF SUR/FIN '99), June 1999.

[137] Y. Li, W. Meng, S. Swathirajan, S. Harris, and G. Doll, US Patent 5, 624, 769, 1997.

[138] L. D. Madsen and L. Weaver, "Characterization of lead oxide thin films produced by chemical vapor deposition," Journal of the American Ceramic Society, vol. 81, no. 4, pp. 988-996, 1998.

[139] A. Heinzel, F. Mahlendorf, and C. Jansen, "Bipolar plates," in Encyclopedia of Electrochemical Power Sources, C. K. Dyer, T. Moseley, Z. Ogumi, and D. A. Rand, Eds., pp. 810-816, Elsevier Science, 2009.

[140] K. Feng, Y. Shen, H. Sun et al., "Conductive amorphous carbon-coated 316L stainless steel as bipolar plates in polymer electrolyte membrane fuel cells," International Journal of Hydrogen Energy, vol. 34, no. 16, pp. 6771-6777, 2009.

[141] R. Tian, J. Sun, and J. Wang, "Study on behavior of plasma nitrided 316L in PEMFC working conditions," International Journal of Hydrogen Energy, vol. 33, no. 24, pp. 7507-7512, 2008.

[142] P. Yi, L. Peng, L. Feng, P. Gan, and X. Lai, "Performance of a proton exchange membrane fuel cell stack using conductive amorphous carbon-coated 304 stainless steel bipolar plates," Journal of Power Sources, vol. 195, no. 20, pp. 7061-7066, 2010.

[143] S. T. Myung, M. Kumagai, R. Asaishi, Y. K. Sun, and H. Yashiro, "Nanoparticle TiN-coated type 310S stainless steel as bipolar plates for polymer electrolyte membrane fuel cell," Electrochemistry Communications, vol. 10, no. 3, pp. 480-484, 2008.

[144] H. Wang, J. A. Turner, X. Li, and G. Teeter, "Process modification for coating $\mathrm{SnO}_{2}:$ F on stainless steels for PEM fuel cell bipolar plates," Journal of Power Sources, vol. 178, no. 1, pp. 238-247, 2008. 

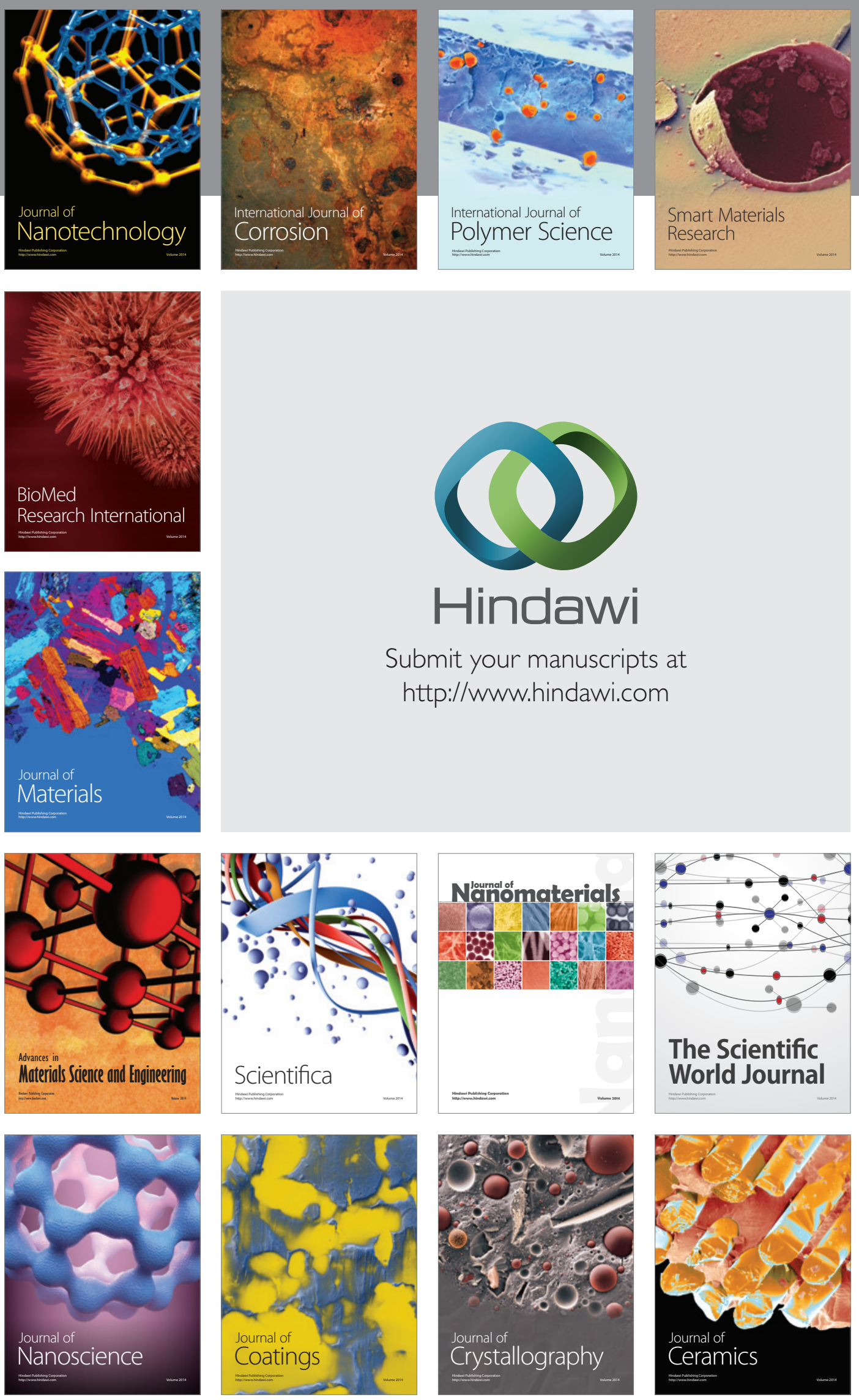

The Scientific World Journal

Submit your manuscripts at

http://www.hindawi.com

\section{World Journal}

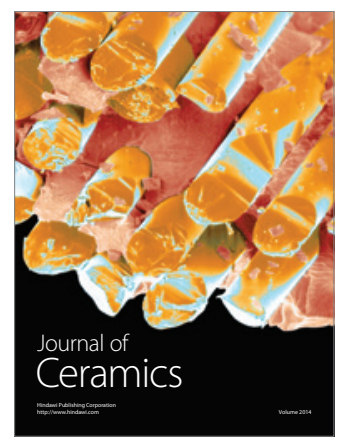

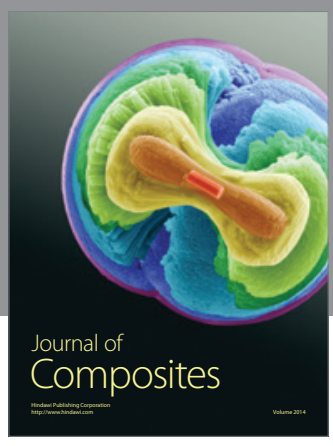
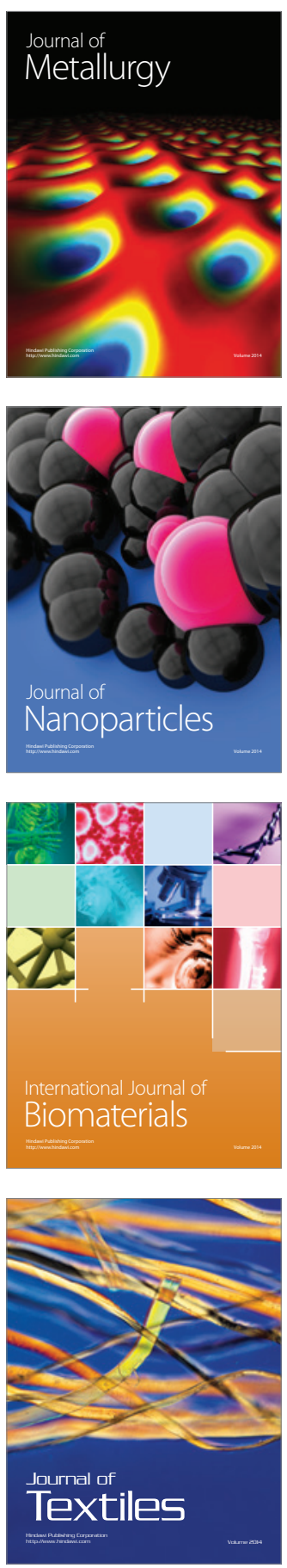